\title{
(6) \\ Mechanisms and therapeutic effectiveness of lactobacilli
} OPEN ACCESS

\author{
Alessandro Di Cerbo, ${ }^{1}$ Beniamino Palmieri, ${ }^{2}$ Maria Aponte, ${ }^{3}$ \\ Julio Cesar Morales-Medina, ${ }^{4}$ Tommaso lannitti ${ }^{5}$
}

- Additional material is published online only. To view please visit the journal online (http://dx.doi.org/10.1136/ jclinpath-2015-202976)

${ }^{1}$ School of Specialization in Clinical Biochemistry, "G. d'Annunzio" University, Chieti, Italy

${ }^{2}$ Department of General Surgery and Surgical Specialties, University of Modena and Reggio Emilia Medical School, Surgical Clinic, Modena, Italy

${ }^{3}$ Department of Agriculture, University of Naples "Federico II", Portici, Naples, Italy

${ }^{4}$ Centro de Investigación en Reproducción Animal CINVESTAV- Universidad Autónoma de Tlaxcala Tlaxcala, México ${ }^{5}$ Department of Neuroscience, Sheffield Institute for Translational Neuroscience (SITraN), University of Sheffield, Sheffield, UK

\section{Correspondence to} Dr Tommaso lannitti, Sheffield Institute for Translational Neuroscience, University of Sheffield, 385A Glossop Road, Sheffield, S10 2HQ, UK tommaso.iannitti@gmail.com

Received 25 February 2015 Revised 2 September 2015 Accepted 14 September 2015 Published Online First 17 November 2015

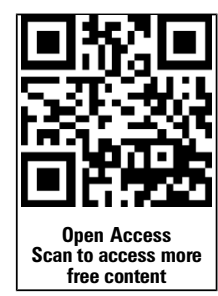

CrossMark

To cite: Di Cerbo $A$,

Palmieri $B$, Aponte $M$, et al. J Clin Pathol 2016;69: 187-203.

\section{ABSTRACT}

The gut microbiome is not a silent ecosystem but exerts several physiological and immunological functions. For many decades, lactobacilli have been used as an effective therapy for treatment of several pathological conditions displaying an overall positive safety profile. This review summarises the mechanisms and clinical evidence supporting therapeutic efficacy of lactobacilli. We searched Pubmed/Medline using the keyword 'Lactobacillus'. Selected papers from 1950 to 2015 were chosen on the basis of their content. Relevant clinical and experimental articles using lactobacilli as therapeutic agents have been included. Applications of lactobacilli include kidney support for renal insufficiency, pancreas health, management of metabolic imbalance, and cancer treatment and prevention. In vitro and in vivo investigations have shown that prolonged lactobacilli administration induces qualitative and quantitative modifications in the human gastrointestinal microbial ecosystem with encouraging perspectives in counteracting pathology-associated physiological and immunological changes. Few studies have highlighted the risk of translocation with subsequent sepsis and bacteraemia following probiotic administration but there is still a lack of investigations on the dose effect of these compounds. Great care is thus required in the choice of the proper Lactobacillus species, their genetic stability and the translocation risk, mainly related to inflammatory disease-induced gut mucosa enhanced permeability. Finally, we need to determine the adequate amount of bacteria to be delivered in order to achieve the best clinical efficacy decreasing the risk of side effects.

\section{INTRODUCTION}

The impact of the gastrointestinal (GI) tract on brain functions and behaviour including anxiety, mood, cognition and pain regulation has been recognised since the 19th century as Hipocrates' dictum stated "Let the food be thy medicine and medicine be thy food". ${ }^{1}$ Therefore, the gut-brain axis has been proposed as a homoeostatic route of communication using neuronal, hormonal and immunological pathways. ${ }^{1-3}$ The GI tract, which is an active part of this axis, is harboured by approximately 100 trillion organisms, mainly anaerobes, which constitute the microbiome and exceed 10 times the overall number of cells present in the human body. ${ }^{4}$ The microbiome plays a key role in the development and functionality of the innate and adaptive immune responses. ${ }^{1}$ Among microbiome-composing organisms, lactobacilli can inhibit the growth of pathogenic bacteria and have a favourable safety profile. ${ }^{6}$ However, different species of the genus Lactobacillus (L.) can produce different particular responses in the host, and the effects exerted by some strains of the same species may not be beneficial.

\section{AIM AND SEARCHING CRITERIA}

In this review, we summarise the experimental and clinical evidence on lactobacilli by providing a comprehensive overview of their efficacy for treatment of numerous pathologies and outlining new therapeutic trends. We searched Pubmed/Medline using the keyword 'Lactobacillus'. Selected papers from 1950 to 2015 were chosen on the basis of their content. Relevant clinical and experimental articles that used lactobacilli as therapeutic agents and written in English language have been included. Clinical findings organised by pathology are summarised in tables $1-15$.

\section{EXPERIMENTAL EVIDENCE}

\section{Adhesion to the gastrointestinal mucosa}

Dietary changes, antibiotic exposure and infections may cause dysbiosis, a perturbation of the microbiome-host symbiosis that favours the invasion and growth of pathogenic species to the detriment of health-promoting bacteria, including lactobacilli, within the GI tract. ${ }^{8}{ }^{9}$ Indeed, adhesion of lactobacilli to the host's GI tract, by means of an interaction with toll-like receptors, is of crucial importance due to its ability to trigger the host's immune response. ${ }^{10} 11$ Nevertheless, adhesion to the GI tract can also be driven by surface proteins and fatty acids, as observed for L. rhamnosus PEN, ${ }^{12}$ and proteinaceous surface layer components, as observed for L. plantarum 91. ${ }^{13}$ Therefore, the ability of lactobacilli to adhere and colonise the GI tract mucosa has been investigated in the clinical setting and is summarised in table $1 .^{14-17}$

\section{Antitumour activity}

Intestinal bacteria produce mutagens such as deoxycholic acid from primary bile acids or by enzymatic conversion when foreign compounds, such as nitroaromatics, azo compounds and nitrates, are ingested. ${ }^{18}$ Lactobacilli are capable of competitively inhibiting carcinogen and mutagen formation, altering overall metabolism, adsorbing and removing toxic and mutagenic metabolites and producing protective metabolites. ${ }^{19}$ In the context of colorectal cancer, the prevention mechanism exerted by probiotics may be a combination of different actions such as intestinal microbiota modification, ${ }^{20-26}$ inactivation of cancerogenic 
Table 1 Lactobacilli displaying ability to adhere to the gastrointestinal tract mucosa

\begin{tabular}{lll}
\hline Bacteria & Dose & Ref. (Design) \\
\hline $\begin{array}{l}\text { L. gasseri SBT2055SR } \\
\text { L. reuteri DSM 12246 }\end{array}$ & $10^{11}$ CFU & ${ }^{14}$ (open study) \\
L. rhamnosus 19070-2 & $10^{10}$ CFU (of each) & ${ }^{17}$ (double-blind \\
L. rhamnosus LGG & & cross-over study) \\
L. acidophilus 821-3 & $1 \times 10^{10}$ CFU & ${ }^{15}$ (open study) \\
L. rhamnosus 19070-2 & $1 \times 10^{10}$ CFU (of each) & ${ }^{16}$ (open study) \\
L. reuteri DSM 12246 & & \\
\hline
\end{tabular}

compounds, ${ }^{27-35}$ competition with putrefactive and pathogenic microbiota, ${ }^{36-40}$ improvement of the host's immune response, ${ }^{41-55}$ enhancement of natural killer cell cytotoxicity ${ }^{56}$ and inhibition of interleukin (IL) 6 production in the colonic mucosa ${ }^{57}$ counteracting cancer development by antiproliferative effects $^{58}$ via regulation of apoptosis and cell differentiation, ${ }^{59-67}$ fermentation of undigested food ${ }^{68-73}$ and inhibition of tyrosine kinase signalling pathways. ${ }^{74}$ Experimental studies have also shown that lactobacilli contained in dietary supplements and fermented food, such as yogurt heat-killed $L$. casei strain Shirota (LC 9018) ${ }^{54}$ reduce colon cancer risk. ${ }^{75-77}$ These activities have been ascribed to the alteration of gut microbiota and, subsequently, to the inhibition or the induction of colonic enzymes controlling the growth of harmful bacteria, improving immune function and stimulating the production of metabolites possessing antitumour activity. Clinical studies showing efficacy of lactobacilli for treatment of cancer have been summarised in table 2.

\section{Antitoxic activity}

Lactobacilli display detoxifying properties and their ability to neutralise toxins ${ }^{81}$ or toxic compounds ${ }^{82}$ is important to maintain the host's health. For instance, L. reuteri CRL 1098 and L. acidophilus CRL 1014 showed the ability to enhance tumour necrosis factor (TNF)- $\alpha$ response to ochratoxin A, a widespread mycotoxin from Aspergillus and Penicillium species. This mycotoxin can contaminate food products ${ }^{83}$ and induce hepatotoxicity, nephrotoxicity and immunotoxicity, ${ }^{84}$ thus increasing TNF- $\alpha$ production and diminishing toxin-induced apoptosis. ${ }^{83}$ Individual treatment with L. plantarum 2017405 , L. fermentum 353, L. acidophilus DSM 21007 and L. rhamnosus GG antagonised C. difficile isolated from faecal specimens from adult patients affected by diarrhoea, as observed by measurement of the inhibition zone. ${ }^{85}$ Another L. strain, L. reuteri $\mathrm{RC}-14,{ }^{86}$ produced small signalling molecules able to interfere with a key regulator of virulence genes, agr. Additionally, L. reuteri $\mathrm{RC}-14$ repressed the expression of toxic shock syndrome toxin-1 in menstrual toxic shock syndrome induced by Staphylococcus (S.) aureus strains. Quantitative real-time polymerase chain reaction (PCR) data revealed that transcription from the toxic shock $t s t$ promoter was strongly inhibited in culture supernatant in presence of L. reuteri RC-14. Moreover, a transcriptional level alteration of virulence-associated regulators was observed, providing a unique mechanism by which endogenous or exogenous lactobacilli can attenuate production of virulence factors. This study highlighted the existence of a crosstalk mechanism between two distinct bacterial signalling systems, alteration in the transcriptional levels of virulence-associated regulators sarA and saeRS and transcription inhibition from Ptst, P2 and P3 promoters, providing a potential defensive mechanism against $S$. aureus infections. Therefore, administration of well-characterised lactobacilli can be helpful to overcome antibiotic-related complications, such as antibiotic resistance. Based on 16SrDNA sequences and noncoding fragments characterisation of different lactobacilli, Fei and coworkers reported a significantly high nitrite degradation capacity exerted by $L$. sp DMDL 9010 after a 24 h fermentation in the medium. ${ }^{87}$ Compound degradation activity of lactobacilli has also been observed for cadmium after high dietary exposure. ${ }^{88}$ In this regard, two L. kefir strains, CIDCA 8348 and JCM 5818, can remove cadmium cations when cocultured with a human hepatoma cell line, HepG2. ${ }^{89}$ Particularly, L. kefir JCM 5818 is more efficient in protecting cells from cadmium toxicity. Therefore, since consumption of harmful metals is a growing medical issue, the regular administration of formulations containing the above mentioned strains might be useful to prevent toxin compound-induced lipid peroxidation and free radical production.

\section{Vaginal colonisation}

Vaginal microbiota is dominated by lactobacilli. ${ }^{90}$ When the balance among bacterial species within this environment is altered, antibacterial defense mechanisms lose their efficacy leading to pathogenic bacteria proliferation. ${ }^{90}$ For instance, reduction in the number of vaginal lactobacilli and their antimicrobial properties (such as lysostaphin expression in order to cleave the cell wall of $S$. aureus thus inhibiting its growth), ${ }^{91}$ and $\mathrm{H}_{2} \mathrm{O}_{2}$ production, ${ }^{92}$ cause bacterial vaginosis, the most common symptomatic microbial imbalance. ${ }^{93}$ In patients affected by bacterial vaginosis, lactobacilli are replaced by Gardnerella vaginalis, ${ }^{92}{ }^{94}$ Candida (C.) albicans, ${ }^{95}$ S. aureus, ${ }^{91} 96$ Neisseria gonorrhoeae ${ }^{40}$ or other anaerobic bacteria. Uncontrolled growth of anaerobic bacteria such as C. albicans and subsequent vaginal colonisation may lead to

Table 2 Clinical studies showing efficacy of lactobacilli for treatment of cancer

\begin{tabular}{|c|c|c|c|}
\hline Bacteria & Dose & Pathology & Ref. (Design) \\
\hline $\begin{array}{l}\text { B. lactis } B b 12 \\
\text { L. rhamnosus GG } \\
+\end{array}$ & $1 \times 10^{10}$ CFU (total) & Colon cancer & ${ }^{39}$ (randomised, double-blind, placebo-controlled study) \\
\hline Oligofructose enriched inulin (SYN1) & $12 \mathrm{~g}$ & & \\
\hline $\begin{array}{l}\text { L. rhamnosus } \mathrm{LC} 705 \\
\text { P. freudenreichii subsp Shermanii }\end{array}$ & $2-5 \times 10^{10}$ CFU (of each) & Liver cancer & ${ }^{78}$ (randomised, double-blind, placebo-controlled study) \\
\hline $\begin{array}{l}\text { B. longum } \\
\text { L. acidophilus } \\
\text { E. faecalis }\end{array}$ & $10^{8} \mathrm{CFU} / \mathrm{g}(0.21 \mathrm{~g})$ (total) & Colorectal cancer & ${ }^{79}$ (open study) \\
\hline $\begin{array}{l}\text { B. natto } \\
\text { L. acidophilus }\end{array}$ & $\begin{array}{l}10 \mathrm{mg} \\
30 \mathrm{mg}\end{array}$ & Colorectal cancer & ${ }^{80}$ (open study) \\
\hline
\end{tabular}


Table 3 Clinical studies of lactobacilli showing efficacy for treatment of vaginal disorders

\begin{tabular}{|c|c|c|c|}
\hline Bacteria & Dose & Pathology & Ref. (Design) \\
\hline L. plantarum P17630 & $>10^{8} \mathrm{CFU}$ & Acute vulvovaginal candidiasis & ${ }^{97}$ (retrospective comparative study) \\
\hline $\begin{array}{l}\text { L. rhamnosus GR-1 } \\
\text { L. fermentum RC-14 }\end{array}$ & $>10^{9} \mathrm{CFU}$ (of each) & $\begin{array}{l}\text { Potential pathogenic bacteria and } \\
\text { yeast vagina colonisation }\end{array}$ & ${ }^{102}$ (open study) \\
\hline $\begin{array}{l}\text { Kramegin }^{\circledR} \\
\text { (L. acidophilus } \\
+ \\
\text { lactic acid and Krameria triandra extract) }\end{array}$ & Not stated & Abnormal cervical cytology & ${ }^{103}$ (open study) \\
\hline $\begin{array}{l}\text { Ellen } A B^{\circledR} \\
\text { (L. gasseri LN40, L. fermentum LN99, L. casei } \\
\text { subsp rhamnosus LN113 and } P \text {. acidilactici LN23 } \\
+ \\
\text { an inert carrying matrix of maltodextrin and } \\
\text { magnesium stearate) }\end{array}$ & $10^{8-10}$ CFU (total) & $\begin{array}{l}\text { Bacterial vaginosis and vulvovaginal } \\
\text { candidiasis }\end{array}$ & $\begin{array}{l}{ }^{104} \text { (randomised double-blind } \\
\text { placebo-controlled study) }\end{array}$ \\
\hline $\begin{array}{l}\text { L. fermentum LF10 } \\
\text { L. acidophilus LA02 } \\
+\end{array}$ & $0.4 \times 10^{9} \mathrm{CFU}$ (of each) & Recurrent vulvovaginal candidiasis & ${ }^{105}$ (clinical study) \\
\hline $\begin{array}{l}\text { Arabinogalactan } \\
+ \\
\text { Fructooligosaccharides }\end{array}$ & $\begin{array}{l}340 \mathrm{mg} \\
241 \mathrm{mg}\end{array}$ & & \\
\hline $\begin{array}{l}\text { L. fermentum LF15 } \\
\text { L. plantarum LP01 } \\
+\end{array}$ & $0.4 \times 10^{9}$ CFU (of each) & Bacterial vaginosis & ${ }^{106}$ (pilot study) \\
\hline Tara gum & $50 \mathrm{mg}$ & & \\
\hline $\begin{array}{l}\text { Florisia }{ }^{\circledR} \\
\text { [L. brevis (CD2), L. salivarius } \\
\text { subsp salicinius (FV2) and L. plantarum (FV9)] }\end{array}$ & $10^{9} \mathrm{CFU}$ (total) & Bacterial vaginosis & $\begin{array}{l}{ }^{107} \text { (randomised, double-blind, } \\
\text { placebo-controlled study) }\end{array}$ \\
\hline $\begin{array}{l}\text { L. rhamnosus GR-1 } \\
\text { L. reuteri } \mathrm{RC}-14\end{array}$ & $2.5 \times 10^{9}$ CFU (of each) & Vaginal flora overgrowth & $\begin{array}{l}{ }^{108} \text { (randomised, double-blind, } \\
\text { placebo-controlled study) }\end{array}$ \\
\hline $\begin{array}{l}\text { EcoVag }^{\circledR} \\
\text { [L. gasseri (Lba EB01-DSM 14869) and L. Rhamnosus } \\
\text { (Lbp PB01-DSM 14870)] }\end{array}$ & $10^{8-9}$ CFU (of each) & Bacterial vaginosis & $\begin{array}{l}{ }^{109} \text { (double-blind, randomised, } \\
\text { placebo-controlled study) }\end{array}$ \\
\hline
\end{tabular}

vulvovaginal candidiasis, ${ }^{97}$ which is estimated to occur at least once during the lifetime of $75 \%$ of the female population. ${ }^{98}$ Vaginal microbial imbalance may also represent an important risk factor for increased risk of urinary tract infections and pregnancy complications, such as endometritis, chorioamnionitis, preterm birth and intrauterine death. ${ }^{99}$ Intravaginal colonisation by bacterial strains with high haemolytic activity and pigment production [eg, group B streptococci (GBS)] is one of the most important risk factors for disease development in newborns. ${ }^{100}$ Therefore, a murine model was proposed to determine if L. reuteri CRL1324 would exert a preventive effect on vaginal colonisation by Streptococcus (St.) agalactiae NH17. ${ }^{100}$ Following L. reuteri CRL1324 administration, a reduced leucocyte influx induced by St. agalactiae NH17 and a preventive effect on its vaginal colonisation were observed prior to the GBS challenge. Although GBS colonization occurs in up to $50-70 \%$ of neonates born from colonized mothers, ${ }^{101}$ the introduction of new antimicrobial agents, such as $L$. reuteri CRL1324, could be considered a valuable and safer alternative to antibiotics to reduce infections caused by GBS. Clinical studies of lactobacilli showing efficacy for treatment of vaginal disorders have been summarised in table 3 .

\section{Cholesterol-lowering activity}

There is an increasing demand for non-pharmacological therapies to improve cholesterol profile due to the cost and side effects associated with available pharmacological treatments for cholesterol-related diseases. Hence great attention has been given to lactobacilli due to their effectiveness in modulating lipid metabolism reducing statin requirement (statins inhibit the enzyme 3-hydroxy-3-methylglutaryl-coenzyme A reductase that produces about $70 \%$ of the total body cholesterol) $)^{110111}$ and serum cholesterol level by means of bile salt hydrolase that has a direct impact on the host's bile salt metabolism accounting for the formation of deconjugated bile acids. ${ }^{112}$ Furthermore, cholesterol-reducing properties were also observed for $L$. oris HMI118, HMI28, HMI43, HMI68 and HMI74 isolated from breast milk. ${ }^{113}$ Although all the tested strains assimilated cholesterol even in the absence of bile salts, surviving in the acidic conditions of the intestine and tolerating high bile concentrations, L. oris HMI68 showed the highest cholesterol assimilation deconjugating sodium glycocholate (the most predominant bile salt in the human intestine) and sodium taurocholate.

Table 4 Clinical studies of lactobacilli showing efficacy for treatment of hypercholesterolaemia

\begin{tabular}{|c|c|c|}
\hline Bacteria & Dose & Ref. (Design) \\
\hline $\begin{array}{l}\text { L. plantarum } \\
\text { CECT } 7527 \\
\text { CECT } 7528 \\
\text { CECT } 7529\end{array}$ & $1.2 \times 10^{9} \mathrm{CFU}$ (total) & $\begin{array}{l}{ }^{118} \text { (controlled, randomised, } \\
\text { double-blind study) }\end{array}$ \\
\hline L. acidophilus L1 & Not stated & $\begin{array}{l}{ }^{119} \text { (double-blind, } \\
\text { placebo-controlled, cross-over } \\
\text { study) }\end{array}$ \\
\hline L. reuteri NCIMB 30242 & $5 \times 10^{9} \mathrm{CFU}$ & $\begin{array}{l}{ }^{120} \text { (double-blind, } \\
\text { placebo-controlled, } \\
\text { randomised, parallel-arm, } \\
\text { multicentre study) }\end{array}$ \\
\hline $\begin{array}{l}\text { L. acidophilus } \\
\text { B. lactis }\end{array}$ & $\begin{array}{l}\text { Not stated } \\
\text { Not stated }\end{array}$ & $\begin{array}{l}{ }^{121} \text { (single-blind and } \\
\text { randomised cross-over study) }\end{array}$ \\
\hline
\end{tabular}


Table 5 Clinical studies of lactobacilli showing inhibitory activity against $H$. pylori infection

\begin{tabular}{|c|c|c|c|}
\hline Bacteria & Dose & Pathology & Ref. (Design) \\
\hline L. johnsonii La1 & $>10^{7} \mathrm{CFU} / \mathrm{mL}(80 \mathrm{~mL})$ & Asymptomatic $H$. pylori infection & ${ }^{173}$ (double-blind, randomised, controlled clinical study) \\
\hline L. gasseri OLL2716 & $1-1.4 \times 10^{7} \mathrm{CFU} / \mathrm{g}(90 \mathrm{~g})$ & H. pylori infection & ${ }^{174}$ (open study) \\
\hline $\begin{array}{l}\text { Enterolactis }^{\circledR} \\
\text { (L. casei subsp casei DG } \\
+ \\
\text { Vitamin B1, B2 and B6) }\end{array}$ & $1.6 \times 10^{9} \mathrm{CFU}$ & H. pylori infection & ${ }^{182}$ (open study) \\
\hline $\begin{array}{l}\text { Actimel }^{\circledR} \text { : } \\
\text { (L. acidophilus HY2177, L. casei } \\
\text { HY2743, B. longum HY8001 and St. } \\
\text { thermophilus B-1) }\end{array}$ & $5 \times 10^{9}$ CFU (total) & H. pylori infection & ${ }^{184}$ (open study) \\
\hline L. reuteri ATCC 55730 & $1 \times 10^{8} \mathrm{CFU}$ & H. pylori infection & ${ }^{185}$ (open study) \\
\hline $\begin{array}{l}\text { Will yogurt } \\
\text { (L. acidophilus HY2177, L. casei } \\
\text { HY2743, B. longum HY8001 and } \\
\text { St. thermophilus B-1) }\end{array}$ & $\begin{array}{l}\geq 1 \times 10^{5} \mathrm{CFU} \\
\geq 1 \times 10^{5} \mathrm{CFU} \\
\geq 1 \times 10^{6} \mathrm{CFU} \\
\geq 1 \times 10^{8} \mathrm{CFU}\end{array}$ & H. pylori infection & ${ }^{186}$ (randomised triple-therapy study) \\
\hline $\begin{array}{l}\text { AB-yogurt } \\
\text { (L. acidophilus La5 and B. lactis } \\
\text { Bb12) }\end{array}$ & $10^{7} \mathrm{CFU} / \mathrm{mL}$ (230 mL) (of each) & H. pylori infection & ${ }^{175}$ (open study) \\
\hline $\begin{array}{l}\text { Genefilus } \mathrm{F} 19^{\odot} \\
\text { (L. paracasei sub. paracasei F19) }\end{array}$ & $12 \times 10^{9} \mathrm{CFU}$ & $\begin{array}{l}H . \text { pylori infection-related } \\
\text { gastroesophageal reflux }\end{array}$ & $\begin{array}{l}{ }^{177} \text { (randomised, double-blind, placebo-controlled } \\
\text { study) }\end{array}$ \\
\hline $\begin{array}{l}\text { L. reuteri Gastrus } \\
\text { (L. reuteri DSM } 17938 \text { and L. reuteri } \\
\text { ATCC PTA 6475) }\end{array}$ & $1 \times 10^{8}$ CFU (total) & H. pylori infection & $\begin{array}{l}{ }^{187} \text { (prospective, double-blind, randomised, } \\
\text { placebo-controlled study) }\end{array}$ \\
\hline L. gasseri OLL2716 & $\geq 10^{9} \mathrm{CFU}$ & H. pylori infection & ${ }^{188}$ (randomised, controlled clinical study) \\
\hline L. brevis CD2 & $20 \times 10^{9} \mathrm{CFU}$ & H. pylori infection & ${ }^{189}$ (open study) \\
\hline
\end{tabular}

Cholesterol assimilation has also been evaluated as a possible therapeutic approach to reduce the risk for cardiovascular diseases. $^{114}$ In this regard, Tomaro-Duchesneau and coworkers investigated the ability of $11 \mathrm{~L}$. strains (L. reuteri NCIMB 11951, 701359, 702655, 701089 and 702656, L. fermentum NCIMB 5221, 8829, 2797, L. rhamnosus ATCC 53103 GG, L. acidophilus ATCC 314 and L. plantarum ATCC 14917) to assimilate cholesterol. While L. plantarum ATCC 14917 was the best cholesterol assimilator in de Man, Rogosa and Sharpe broth, L. reuteri NCIMB 701089 assimilated over 67\% of cholesterol under physiological intestinal conditions. The hypocholesterolaemic effect of all strains, particularly of $L$. reuteri NCIMB 701089, was linked to intrinsic bile salt hydrolase activity, assimilation and incorporation in cellular membranes and compound production, for example, ferulic acid, ${ }^{115}$ able to inhibit the activity of enzymes, including 3-hydroxy-3methylglutaryl-coenzyme A reductase. ${ }^{116}$ More recently, cholesterol-reducing L. spp. GI6, GI9, GI11 and GI15 were also isolated from traditionally fermented south Indian koozh and gherkin (a variety of cucumber). ${ }^{117} \mathrm{~L}$. GI9 was able to survive at $\mathrm{pH} 2.0$ and $0.50 \%$ bile salt for $3 \mathrm{~h}$ without losing its viability also exhibiting the maximum cholesterol reduction. Nevertheless, all tested lactobacilli exhibited inhibitory activity against several pathogens including Escherichia coli MTCC

Table 6 Clinical studies of lactobacilli showing efficacy for treatment of oxaluria

\begin{tabular}{lll}
\hline Bacteria & Dose & Ref. (Design) \\
\hline $\begin{array}{l}\text { L. acidophilus } \\
\text { L. plantarum }\end{array}$ & $8 \times 10^{11}$ CFU (of each) & ${ }^{197}$ (open study) \\
St. thermophilus & \\
B. infantis & \\
L. brevis (CD2) & \\
\hline
\end{tabular}

1089, Pseudomonas (P.) aeruginosa MTCC 2642, S. aureus MTCC 7443, Klebsiella (K.) pneumoniae MTCC 7028, Bacillus subtilis MTCC 8561 and C. albicans BS3 and were able to deconjugate bile salts. Clinical studies of lactobacilli showing efficacy for treatment of hypercholesterolaemia have been summarised in table 4.

\section{Antioxidant activity}

Lactobacilli can prevent lipid peroxidation ${ }^{122}$ and free oxygen radical production ${ }^{123}$ due to their ability to create the low oxidation-reduction potential required for their optimal growth. ${ }^{124}$ Amaretti and coworkers combined the strains Bifidobacterium (B.) animalis subsp lactis DSMZ 23032, L. acidophilus DSMZ 23033 and L. brevis DSMZ 23034 and administered them for 18 days to rats previously treated with doxorubicin, an anthracycline antibiotic. ${ }^{125}$ Analysis of plasma antioxidant activity, glutathione concentration, as well as levels of reactive oxygen species, revealed a reduction in doxorubicin-induced oxidative stress, thus supporting antioxidant activity of these probiotics.

\section{Antibacterial and antiviral activity}

Probiotic strains beneficially affect the host by replacing pathogenic bacteria in the GI tract and modulating immune responses. ${ }^{126}$ Experimental studies have shown that lactobacilli, which can adhere to enterocytes, are effective in preventing the enteropathogen-mediated infection by competing for nutrients $^{127}$ and binding sites (eg,inducing intestinal mucin gene expression), ${ }^{128-132}$ by secreting antimicrobial substances ${ }^{133}$ such as organic acids, ${ }^{134-142}$ bacteriocins ${ }^{143-145}$ and hydrogen peroxide $^{146-152}$ and eventually by counteracting the spread within the colonised body, ${ }^{153-155}$ reducing gut $\mathrm{pH}^{133} 141156$ and producing biosurfactants. ${ }^{157-159}$ As far as bacterial activity is concerned, L. plantarum GK81, L. acidophilus GK20 and L. plantarum JSA22 inhibit Salmonella spp infection in intestinal epithelial 
Table 7 Clinical studies of lactobacilli showing efficacy for treatment of mastitis

\begin{tabular}{lll}
\hline Bacteria & Dose & Pathology \\
\hline $\begin{array}{ll}\text { L. fermentum CECT5716 } \\
\text { L. salivarius CECT5713 }\end{array}$ & $1 \times 10^{9}$ CFU (of each) & Infectious mastitis \\
$\begin{array}{l}\text { L. salivarius CECT5713 and } \\
\text { L. gasseri CECT5714 }\end{array}$ & $1 \times 10^{10}$ CFU (of each) & induced by S. epidermidis or S. aureus \\
+ & & Mastitis induced by \\
a matrix of methylcellulose & Not stated & S. epidermidis or S. aureus \\
\hline
\end{tabular}

cells ${ }^{160161}$ and L. acidophilus strain inhibits various pathogenic bacteria including $P$. aeruginosa, E. coli, Enterobacter and K. spp. ${ }^{150}$ With reference to antiviral activity, lactobacilli harbour surface layer proteins involved in the enhancement of viral entry. ${ }^{162}$ Moreover, increasing data indicate that abnormal vaginal flora lacking lactobacilli can facilitate viral sexually transmitted disease diffusion such as in the case of HIV, ${ }^{163}$ human papilloma virus ${ }^{164}$ and herpes simplex virus $2 .{ }^{165}$ In this context, lactobacilli can exert an important role protecting the vaginal environment and reducing the risk of virus transmission.

\section{Helicobacter pylori infection}

Helicobacter (H.) pylori, a gram-negative microaerophilic human gastric pathogen, is the main cause of chronic gastritis, gastric cancer and peptic ulcer disease. ${ }^{166}$ Antibiotic treatment for $H$. pylori infection is associated with serious side effects and therefore there is an increasing demand for new treatments. Lactobacilli ${ }^{167} 168$ have been extensively investigated for treatment of $H$. pylori infections. Numerous L. strains, that is, L. gasseri Chen, L. plantarum $18,{ }^{167}$ L. gasseri OLL2716, ${ }^{168}$ L. reuteri, ${ }^{169}$ L. rhamnosus GG, L. rhamnosus Lc705, Propionibacterium (P.) freudenreichii subsp shermanii $\mathrm{Js},{ }^{170}$ L. delbrueckii subsp bulgaricus 48, 144 and $\mathrm{GB},{ }^{171}$ L. rhamnosus LC705, P. freudenreichii ssp shermanii JS, ${ }^{168}$ L. acidophilus LB, ${ }^{172}$ L. plantarum MLBPL1, L. rhamnosus GG and L $_{\text {lactis }}{ }^{137}$ possess a neutralising activity against $H$. pylori. The same activity was also observed for heat-killed L. johnsonii Lal and L. helveticus ${ }^{173}$ as well as for L. gasseri OLL2716, ${ }^{174}$ as measured by ${ }^{13} \mathrm{C}$-urea breath test. The suppressive effect of lactobacilli on $H$. pylori infection in vivo and in vitro has been reviewed. ${ }^{175-177}$ For instance, L. johnsonii 1088 suppressed gastric acid secretion in mice via decreasing the number of gastrin-positive cells in the stomach. ${ }^{176}$ Therefore L. johnsonii 1088 can be considered a valid add-on therapy to the gold standard treatment for $H$. pylori eradication consisting of a proton pump inhibitor (PPI), amoxicillin and clarithromycin, and can also be used for prophylaxis of gastroesophageal reflux disease that can develop following $H$. pylori eradication. Nevertheless, the use of a PPI can also modify the gut microbiota causing dysbiosis. ${ }^{178-180}$ In this regard, adding L. paracase $i$ subsp paracase $i$ F19 to triple therapy is a promising combination to counteract the effects of PPIs on intestinal dysbiosis. ${ }^{181}$ Clinical studies of lactobacilli showing inhibitory activity against H. pylori infection have been summarised in table 5 .

\section{Kidney disease}

The last stage of chronic kidney disease induces an increase in plasma concentration of uraemic wastes and requires kidney transplantation or chronic dialysis. ${ }^{190}$ Many studies support the probiotic approach as an alternative therapy for management of end-stage renal disease ${ }^{191}$ and to relieve the 'uraemic' condition. ${ }^{189} 192-194$ In particular, a high urease activity was observed for S. spp, L. casei, K. aerogenes and Enterococcus faecium in the sheep rumen. ${ }^{192}$ At the same time, the ability to degrade biogenic amines (BAs) was also assessed by Capozzi and coworkers. ${ }^{193}$ They isolated two lactobacilli (L. plantarum NDT 09 and L. plantarum NDT 16) from wine and found that they were able to degrade tyramine $(22.12 \%)$ and putrescine (31.09\%), respectively. L. casei $4 \mathrm{a}$ and $5 \mathrm{~b}$, isolated from Zamorano cheese, also inhibited tyramine along with histamine, another BA. ${ }^{194}$ However, BA degradation is not the only mechanism under investigation for treatment of end-stage renal disease and uraemic condition. The ability to degrade oxalate and to survive within the GI tract of a range of $B$. and $L$. species, isolated from the canine and feline GI tract, has also been evaluated. In vitro oxalate degradation was detected for 11 out of $18 \mathrm{~L}$. strains ( $8 \mathrm{~L}$. animalis and $3 \mathrm{~L}$. murinus $)$, but not for any of the $B$. strains. ${ }^{195}$ Rats were fed on four selected strains (L. animalis 223C, L. murinus 1222, L. animalis 5323 and L. murinus 3133) for 4 weeks; urinary oxalate levels were

Table 8 Clinical studies of lactobacilli showing immunomodulatory activity in various pathologies

\begin{tabular}{|c|c|c|c|}
\hline Bacteria & Dose & Pathology & Ref. (Design) \\
\hline L. salivarius LSO1 & $1 \times 10^{9}$ CFU (of each) & Moderate/severe atopic dermatitis & ${ }^{223}$ (randomised double-blinded active treatment vs placebo study) \\
\hline \multicolumn{4}{|l|}{ B. breve $\mathrm{BR} 03$} \\
\hline & & & \\
\hline maltodextrin & Not stated & & \\
\hline $\begin{array}{l}\text { proBiotik }^{\circledR} \\
\text { (B. bifidum, L. acidophilus, L. casei and } \\
\text { L. salivarius) }\end{array}$ & $2 \times 10^{9}$ CFU (total) & Atopic dermatitis & ${ }^{207}$ (double-blind, randomised, placebo-controlled study) \\
\hline L. pentosus b240 & $2 \times 10^{10} \mathrm{CFU}$ & Common cold & ${ }^{224}$ (randomised, double-blind, placebo-controlled study) \\
\hline $\begin{array}{l}\text { Yakult }^{\circledR} \\
\text { (L. casei Shirota) }\end{array}$ & $6.5 \times 10^{9} \mathrm{CFU}$ & Allergic rhinitis & ${ }^{210}$ (double-blind, placebo-controlled study) \\
\hline L. paracasei-33 & $2 \times 10^{9} \mathrm{CFU}$ & Allergic rhinitis & ${ }^{216}$ (randomised, double-blind, placebo-controlled study) \\
\hline L. acidophilus L-92 & Not stated & Atopic dermatitis & ${ }^{225}$ (double-blind, randomised, clinical study) \\
\hline
\end{tabular}


Table 9 Clinical studies of lactobacilli showing efficacy for treatment of gastrointestinal pathologies

\begin{tabular}{|c|c|c|c|}
\hline Bacteria & Dose & Pathology & Ref. (Design) \\
\hline $\begin{array}{l}\text { VSL\# }{ }^{\circledR} \\
\text { (L. casei, L. plantarum, L. acidophilus, L. delbrueckii } \\
\text { subsp bulgaricus, B. longum, B. breve, } \\
\text { B. infantis and St. thermophilus) }\end{array}$ & $5 \times 10^{11} \mathrm{CFU} / \mathrm{g}(3 \mathrm{~g})$ (total) & Chronic pouchitis & ${ }^{230}$ (open study) \\
\hline $\begin{array}{l}\text { Yakult }^{\circledR} \\
\text { (L. casei Shirota) }\end{array}$ & $6.5 \times 10^{9} \mathrm{CFU}$ & Constipation & ${ }^{231}$ (open study) \\
\hline L plantarum SN13T & $2 \times 10^{8} \mathrm{CFU}$ & Constipation & ${ }^{232}$ (double-blind, randomised study) \\
\hline $\begin{array}{l}\text { VSL\#3 } \\
\text { (L. casei, L. plantarum, L. acidophilus, L. delbrueckii } \\
\text { subsp bulgaricus, B. longum, B. breve, } \\
\text { B. infantis and St. thermophilus) }\end{array}$ & $5 \times 10^{11} \mathrm{CFU} / \mathrm{g}(3 \mathrm{~g})$ (total) & Ulcerative colitis & ${ }^{233}$ (open study) \\
\hline
\end{tabular}

significantly reduced only in those rats fed on L. animalis 5323 and L. animalis 223C. Oxalate-degrading activity has also been assessed for other lactobacilli. ${ }^{196}$ L. paracasei LPC09 displayed the highest oxalate-degrading activity converting $68.5 \%$ of ammonium oxalate followed by L. gasseri LGS01 (68.4\%), L. gasseri LGS02 (66.2\%), L. acidophilus LA07 (54.2\%) and L. acidophilus LA02 (51.3\%). The use of lactobacilli as agents able to integrate into the host's gut microbiota may thus be considered helpful in reducing oxaluria and preventing or decreasing the incidence and severity of kidney stone formation. Clinical studies of lactobacilli showing efficacy for treatment of oxaluria have been summarised in table 6 .

\section{Mastitis}

Mastitis is an infectious inflammation of one or more breast lobules ${ }^{198}$ with $S$. aureus and S. epidermidis being the most frequent aetiological agents ${ }^{199}$ and with a prevalence of 3-33\% among breastfeeding mothers. ${ }^{200}$ Multidrug resistance and biofilm formation by pathogenic bacteria account for the lack of efficacy of antibiotics used for treatment of mastitis. ${ }^{201}$ In this context, new strategies based on probiotics, as alternatives or complements to antibiotic therapy for the management of mastitis, are gaining a prominent role. Clinical studies of lactobacilli showing efficacy for treatment of mastitis have been summarised in table 7 .

\section{Immunomodulatory activity}

Lactobacilli are potential adjuvants triggering mucosal and systemic immune responses. ${ }^{204}$ The immunomodulatory effects of lactobacilli observed in various physiological systems include increased natural killer cell cytotoxicity ${ }^{205} 206$ and induction of interferon- $\gamma$ production ${ }^{205-213}$ and cytokine expression. ${ }^{205-210}$
212-216 In order to exert these immunomodulatory effects, lactobacilli must resist to digestive system processes $^{217}$ and adhere to the host's intestinal epithelium. ${ }^{218}$ Lactobacilli (in particular L. acidophilus) can also be administered together with bifidobacteria in order to enhance the immune system. ${ }^{219} 220$ This effect is accomplished by enhancing systemic/local immunity ${ }^{221}$ and concurrently attenuating systemic stress response. ${ }^{22}$ Clinical studies of lactobacilli showing immunomodulatory activity in various pathologies have been summarised in table 8 .

\section{Gastrointestinal pathologies}

Even if the pathogenesis of irritable bowel syndrome (IBD) remains unknown, the luminal microbiome plays a key role in triggering and maintaining a balanced environment within the GI tract. ${ }^{226}$ Dysbiosis may also play a key role in IBD. ${ }^{227}$ Evidence from animal models ${ }^{228}$ and clinical observations ${ }^{229}$ outlined the putative therapeutic role of probiotic strains for IBD treatment. Restoring microbiota-host symbiosis can represent a promising approach for treatment of the above mentioned conditions and can be applied to other GI pathologies, as summarised in table 9.

\section{Gastrointestinal tract survival}

Strains belonging to $L$. and $B$. genera are the most studied in clinical practice. $^{234}$ The number of bacterial strains that reach the gut mucosa and colon, depends on several factors such as strain used, gastric transit survival, ${ }^{15} 235$ and acid and bile tolerance. ${ }^{236}$ Clinical studies of lactobacilli showing ability to survive in the GI tract have been summarised in table 10 .

Table 10 Clinical studies of lactobacilli showing ability to survive in the gastrointestinal tract

\begin{tabular}{|c|c|c|c|}
\hline Bacteria & Dose & Site & Ref. (Design) \\
\hline L. acidophilus $821-3$ & $1 \times 10^{10} \mathrm{CFU}$ & Gastrointestinal tract & ${ }^{15}$ (open study) \\
\hline $\begin{array}{l}\text { L. acidophilus } \\
\text { B. sp }\end{array}$ & $\begin{array}{l}1 \times 10^{8} \mathrm{CFU} / \mathrm{g}(100 \mathrm{~g}) \\
1 \times 10^{7} \mathrm{CFU} / \mathrm{g}(100 \mathrm{~g})\end{array}$ & Small intestine & ${ }^{237}$ (open study) \\
\hline L. casei Shirota & $1 \times 10^{8} \mathrm{CFU} / \mathrm{mL}(100 \mathrm{~mL})$ & Gastrointestinal tract & ${ }^{238}$ (14-day baseline, ingestion and follow-up periods) \\
\hline $\begin{array}{l}\text { L. acidophilus LA02 (DSM 21717) } \\
\text { L. rhamnosus LR04 (DSM 16605) } \\
\text { L. rhamnosus GG (ATCC 53103) } \\
\text { L. rhamnosus LR06 (DSM 21981) } \\
\text { B. lactis BS01 (LMG P-21384) }\end{array}$ & $5 \times 10^{9}$ CFU (of each) & Gastrointestinal tract & ${ }^{239}$ (double-blind, randomised, cross-over study) \\
\hline $\begin{array}{l}\text { L. plantarum LP01 (LMG P-21021) } \\
\text { B. breve BR03 (DSM 16604) }\end{array}$ & $1 \times 10^{9}$ CFU (of each) & Gastrointestinal tract & ${ }^{240}$ (double-blind, randomised, cross-over study) \\
\hline $\begin{array}{l}\text { Lakcid }^{\circledR} \mathrm{L} \\
\text { (L. rhamnosus 573/1, } 573 \mathrm{~L} / 2 \text { and 573L3) }\end{array}$ & $1.2 \times 10^{10} \mathrm{CFU}$ & Gastrointestinal tract & $\begin{array}{l}{ }^{241} \text { (prospective, double-blinded, placebo-controlled } \\
\text { randomised study) }\end{array}$ \\
\hline
\end{tabular}


Table 11 Clinical studies of lactobacilli showing efficacy for treatment of diarrhoea

\begin{tabular}{|c|c|c|c|}
\hline Bacteria & Dose & Pathology & Ref. (Design) \\
\hline $\begin{array}{l}\text { Actimel }^{\circledR} \\
\text { (L. casei DN 114001) }\end{array}$ & $10^{10} \mathrm{CFU}$ & Antibiotic-associated diarrhoea & ${ }^{249}$ (observational study) \\
\hline $\begin{array}{l}\text { Balance }{ }^{\mathrm{TM}} \\
\text { (L. casei, L. rhamnosus, } \\
\text { L. acidophilus, L. bulgaricus, } \\
\text { B. strains, B. breve, B. longum } \\
\text { and St. thermophilus) }\end{array}$ & $1 \times 10^{8}$ CFU (total) & H. pylori infection-associated diarrhoea & ${ }^{250}$ (randomised placebo-controlled triple-blind study) \\
\hline $\begin{array}{l}\text { L. acidophilus } \\
\text { L.rhamnosus } \\
\text { B. bifidum } \\
\text { B. longum } \\
\text { E. faecium } \\
+ \\
\text { fructo-oligosaccharide }\end{array}$ & $2.5 \times 10^{9}$ CFU (total) & Acute diarrhoea & $\begin{array}{l}{ }^{251} \text { (prospective randomised, multicentre single-blinded clinical } \\
\text { study) }\end{array}$ \\
\hline $\begin{array}{l}\text { L. acidophilus (CUL60, NCIMB } \\
30157 \text { and CUL21, NCIMB } \\
30156), \text { B. bifidum (CUL20, } \\
\text { NCIMB 30153) and B. lactis } \\
\text { (CUL34, NCIMB 30172) }\end{array}$ & $6 \times 10^{10}$ CFU (total) & Antibiotic-associated diarrhoea & ${ }^{252}$ (prospective, parallel group study) \\
\hline $\begin{array}{l}\text { Probiotical } \\
\text { (S. thermophilus, L. rhamnosus, } \\
\text { L. acidophilus, } \\
\text { B. lactis and B. infantis } \\
+ \\
\text { Fructooligosaccharides } \\
+ \\
\text { Ascorbic acid) }\end{array}$ & $\begin{array}{l}6.5 \times 10^{9} \text { CFU (of each) } \\
20 \mathrm{mg} \\
1.2 \mathrm{mg}\end{array}$ & Acute gastroenteritis & $\begin{array}{l}{ }^{253} \text { (randomised, prospective placebo-controlled parallel clinical } \\
\text { study) }\end{array}$ \\
\hline $\begin{array}{l}\text { NAN }{ }^{\circledR} \\
\text { (L. acidophilus, L. rhamnosus, } \\
\text { B. longum and S. boulardii) }\end{array}$ & $\begin{array}{l}6.625 \times 10^{7} \mathrm{CFU} \\
3.625 \times 10^{7} \mathrm{CFU} \\
8.75 \times 10^{6} \mathrm{CFU} \\
1.375 \times 10^{7} \mathrm{CFU}\end{array}$ & Acute rotavirus diarrhoea & ${ }^{254}$ (prospective, double-blind, randomised study) \\
\hline L. rhamnosus 35 & $6 \times 10^{8} \mathrm{CFU}$ & Acute rotaviral gastroenteritis & ${ }^{255}$ (open-label randomised study) \\
\hline $\begin{array}{l}\text { L. rhamnosus (strains } \mathrm{E} / \mathrm{N} \text {, } \\
\text { Oxy and Pen) }\end{array}$ & $2 \times 10^{10}$ CFU (of each) & Antibiotic-associated diarrhoea & ${ }^{256}$ (double-blind, randomised, placebo-controlled study) \\
\hline $\begin{array}{l}\text { L. acidophilus LB } \\
+ \\
\text { spent culture medium }\end{array}$ & $\begin{array}{l}10^{9} \mathrm{CFU} \\
160 \mathrm{mg}\end{array}$ & Non-rotavirus diarrhoea & ${ }^{257}$ (randomised, double-blind, placebo-controlled clinical study) \\
\hline $\begin{array}{l}\text { Lakcid }^{\circledR} \mathrm{L} \\
{[\text { L. rhamnosus }(573 \mathrm{~L} / 1 \text {, }} \\
573 \mathrm{~L} / 2 \text { and } 573 \mathrm{~L} / 3) \text { ] }\end{array}$ & $1.2 \times 10^{10} \mathrm{CFU}$ (total) & Infectious diarrhoea & ${ }^{258}$ (randomised, double-blind, placebo-controlled study) \\
\hline L. paracasei ST11 & $10^{10} \mathrm{CFU}$ & Non-rotavirus diarrhoea & ${ }^{259}$ (randomised, double-blind, placebo-controlled clinical study) \\
\hline L. casei CERELA & $\begin{array}{l}10^{11} \mathrm{CFU} / \mathrm{g}(175 \mathrm{~g}) \\
\text { (of each) }\end{array}$ & Persistent diarrhoea & ${ }^{260}$ (double-blind study) \\
\hline $\begin{array}{l}\text { L. acidophilus CERELA } \\
\text { S. boulardii } \\
\text { L. rhamnosus 19070-2 } \\
\text { L. reuteri DSM } 12246\end{array}$ & $10^{10} \mathrm{CFU}$ (of each) & Acute diarrhoea & ${ }^{261}$ (randomised placebo-controlled study) \\
\hline $\begin{array}{l}\text { L. casei CERELA } \\
\text { L. acidophillus CERELA }\end{array}$ & $\begin{array}{l}\text { Not stated } \\
\text { Not stated }\end{array}$ & $\begin{array}{l}\text { Bacterial overgrowth-related chronic } \\
\text { diarrhoea }\end{array}$ & ${ }^{262}$ (randomised, double-blind study) \\
\hline L. reuteri & $10^{10-11} \mathrm{CFU} / \mathrm{g}(1 \mathrm{~g})$ & Acute diarrhoea & ${ }^{263}$ (randomised, placebo-controlled study) \\
\hline
\end{tabular}

\section{Diarrhoea}

Imbalance in the gut flora can cause diarrhoea, enteritis and colitis, among other diseases. VSL\#3 (St. thermophilus, B. breve, B. longum, B. infantis, L. acidophilus, L. plantarum,
L. casei and L. bulgaricus) and L. casei DN-114 001 administration decreased the incidence and frequency of radiation therapy-induced diarrhoea. ${ }^{242}$ Diarrhoea is also frequent during antibiotic therapy causing gut flora imbalance. ${ }^{243} 244$

Table 12 Clinical studies of lactobacilli showing efficacy for treatment of periodontal disease

\begin{tabular}{llll}
\hline Bacteria & Dose & Pathology & Ref. (Design) \\
\hline L. salivarius WB21 & $6.7 \times 10^{8}$ CFU & Severe periodontitis treatment & 274(randomised clinical study) \\
+ & $280 \mathrm{mg}$ & & \\
Xylitol & $1 \times 10^{8}$ CFU (of each) & Gingival inflammation & 275 (double-blind placebo-controlled study) \\
$\begin{array}{l}\text { L. reuteri ATCC 55730 } \\
\text { L. reuteri ATCC PTA 5289 }\end{array}$ & & & \\
\hline
\end{tabular}


Table 13 Clinical studies of lactobacilli showing efficacy for treatment of type-2 diabetes

\begin{tabular}{lll}
\hline Bacteria & Dose & Ref. (Design) \\
\hline L. acidophilus & $2 \times 10^{9} \mathrm{CFU}$ & ${ }^{282}$ (randomised double-blind \\
L. casei & $7 \times 10^{9} \mathrm{CFU}$ & placebo-controlled clinical study) \\
L. rhamnosus & $1.5 \times 10^{9} \mathrm{CFU}$ & \\
L. bulgaricus & $2 \times 10^{8} \mathrm{CFU}$ & \\
B. breve & $2 \times 10^{10} \mathrm{CFU}$ & \\
B. longum & $7 \times 10^{9} \mathrm{CFU}$ & \\
St. thermophilus & $1.5 \times 10^{9} \mathrm{CFU}$ & \\
+ & & \\
fructo-oligosaccharide & $100 \mathrm{mg}$ & \\
\hline
\end{tabular}

Clostridium (C.) difficile infection, a gram positive, sporeforming anaerobe, can cause antibiotic-associated diarrhoea and colitis in humans. ${ }^{245} 246$ Boonma and coworkers investigated the probiotic effect of L. rhamnosus L34 and L. casei L39, two vancomycin-resistant lactobacilli, on the suppression of IL-8 production in response to C. difficile infection. ${ }^{247}$ While L. casei L39 suppressed the activation of phosphonuclear factor $\kappa$-light-chain-enhancer of activated B cells and phospho-c-Jun in HT-29 cells, L. rhamnosus L34 and L. casei L39 decreased the production of C. difficile-induced granulocyte-macrophage colony-stimulating factor. Moreover, L. acidophilus GP1B cell extract decreased transcriptional levels of luxS, tcdA, tcdB and txeR genes of C. difficile, thus reducing virulence in vitro. ${ }^{248}$ In vivo, survival rates at 5 days for mice that received C. difficile and L. acidophilus GP1B cell extract or L. acidophilus GP1B were reduced up to $80 \%$. Therefore, in vitro and in vivo investigations have showed that lactobacilli presented antibacterial effects. Clinical studies of lactobacilli showing efficacy for treatment of diarrhoea have been summarised in table 11 .

\section{Periodontal disease}

Periodontal diseases can be divided into gingivitis and periodontitis. $^{264}$ While the first condition is characterised by inflammation of the gingiva, ${ }^{265}$ the second is a progressive destructive disease which involves tooth supporting tissues such as the alveolar bone. ${ }^{266}$ Periodontitis is mainly characterised by the presence of Porphyromonas gingivalis, Treponema denticola, Tannerella forsythia and Aggregatibacter actinomycetemcomitans which colonise the subgingival sites escaping the host defense system and eventually causing tissue damage. ${ }^{267}$ Among antimicrobial and bacteriostatic agents, chlorhexidine is the gold standard for treatment of periodontitis because of its broadspectrum antibacterial activity. ${ }^{268-270}$ However, a number of side effects, such as brown teeth discolouration, salt taste perturbation, oral mucosal erosions and enhanced supragingival calculus formation, have been reported and they have limited chlorhexidine long-term use. ${ }^{271}$ Evidence has shown the effectiveness of lactobacilli in reducing gingival inflammation and the number of cariogenic periodontopathogenic bacteria. ${ }^{272}$ Further studies have shown that lactobacilli reduced the prevalence of moderate-to-severe gingival inflammation and improved plaque index (clinically used to measure the state of oral hygiene) $)^{273274}$ as well as decreased the levels of the proinflammatory cytokines TNF- $\alpha$, IL- 8 and IL- $1 \beta .{ }^{275}$ Saha and coworkers investigated the role of selected lactobacilli in St. mutans inhibition. $^{276}$ L. reuteri strains NCIMB 701359, NCIMB 701089, NCIMB 702655 and NCIMB 702656 inhibited St. mutans to non-detectable levels $(<10 \mathrm{CFU} / \mathrm{mL})$ suggesting their use as therapeutic agents for caries and periodontal disease. Moreover, L. fermentum NCIMB 5221 inhibited St. mutans buffering the $\mathrm{pH}$ (4.18) of saliva containing this pathogenic microbe and coaggregating with it also showing high levels of sucrose consumption. Altogether, these studies suggest that lactobacilli may improve oral health and reduce periodontopathogenic bacteria. Clinical studies of lactobacilli showing efficacy for treatment of periodontal diseases have been summarised in table 12 .

\section{Diabetes}

Diabetes, a chronic metabolic disease, is characterised by elevated blood glucose levels due to either insufficient insulin production by $\beta$-islet cells (type- 1 diabetes) of the pancreas or

Table 14 Clinical studies of lactobacilli showing efficacy for treatment of various pathologies

\begin{tabular}{|c|c|c|c|}
\hline Bacteria & Dose & Pathology & Ref. (Design) \\
\hline L. casei Shirota & Not stated & Ventilator-associated pneumonia & $\begin{array}{l}{ }^{291} \text { (prospective, randomised, open-label controlled } \\
\text { study) }\end{array}$ \\
\hline $\begin{array}{l}\text { Synbiotic } 2000 \\
\text { (P. pentosaceus 5-33:3, L. mesenteroides } \\
\text { 32-77:1, } \\
\text { L. paracasei } 19 \text { and L. plantarum } 2362 \\
+ \\
\text { inulin, } \beta \text {-glucan, resistant } \\
\text { starch and pectin) }\end{array}$ & $1 \times 10^{10}$ CFU (of each) & Severe acute pancreatitis & ${ }^{292}$ (prospective, randomised, double-blind study) \\
\hline $\begin{array}{l}\text { Ecologic } 641^{\circledR} \text { : } \\
\text { (L. acidophilus, L. casei, L. salivarius, } \\
\text { Lactococcus lactis, B. bifidum and B. lactis } \\
+ \\
\text { cornstarch and maltodextrins) }\end{array}$ & $10^{10}$ CFU (total) & Severe acute pancreatitis & $\begin{array}{l}{ }^{293} \text { (multicentre randomised, double-blind, } \\
\text { placebo-controlled study) }\end{array}$ \\
\hline & Not stated & & \\
\hline $\begin{array}{l}\text { Genefilus } \mathrm{F}^{\circ}{ }^{\odot} \\
\text { (L. paracasei subsp paracasei F19 } \\
+ \\
\text { high-fibre diet) }\end{array}$ & $12 \times 10^{9} \mathrm{CFU}$ & $\begin{array}{l}\text { Symptomatic uncomplicated diverticular } \\
\text { disease }\end{array}$ & $\begin{array}{l}{ }^{294} \text { (multicentre, randomised, controlled, open } \\
\text { parallel-group study) }\end{array}$ \\
\hline L. GG & $>5 \times 10^{10} \mathrm{CFU}$ & Cirrhosis & ${ }^{295}$ (open study) \\
\hline
\end{tabular}


Table 15 Clinical studies reporting side effects associated with Lactobacillus therapy

\begin{tabular}{|c|c|c|c|}
\hline Bacteria & Effect/s & Patient(s) clinical history & Ref. \\
\hline L. jensenii & Endocarditis & $\begin{array}{l}\text { An immunocompetent } 47 \text {-year-old man with mitral valve replacement treated with teicoplanin and } \\
\text { meropenem }\end{array}$ & 302 \\
\hline L. paracasei & Endocarditis & A patient (18 years) with trisomy 21 treated with chloramphenicol & 303 \\
\hline L. rhamnosus GG & Bacteraemia & $\begin{array}{l}\text { Eleven patients with immunosuppression, prior prolonged hospitalisation and prior surgical interventions } \\
\text { treated with antimicrobials }\end{array}$ & 317 \\
\hline $\begin{array}{l}\text { L. acidophilus } \\
\text { L. bulgaricus }\end{array}$ & Bloodstream infections & The maximum estimated incidence of bacteraemia during an 8 -year period was $0.2 \%$ & 322 \\
\hline L. rhamnosus & Bacteraemia & Sixteen nosocomial infections associated with immunosuppression $(66 \%)$ and catheters $(83 \%)$ & 312 \\
\hline $\begin{array}{l}\text { L. rhamnosus } \\
\text { L. curvatus } \\
\text { L. delbrueckii subsp } \\
\text { lactis } \\
\text { L. paracasei }\end{array}$ & Bacteraemia & Six cases of bacteraemia in hospitalised patients, five with a depressed immune status & 306 \\
\hline L. rhamnosus & Hepatic abscess and bacteraemia & A 73 year-old woman with antecedent of diabetes mellitus treated with ampicillin plus gentamicin & 316 \\
\hline L. rhamnosus & Catheter-related bacteraemia & A patient who underwent a single-lung transplant & 308 \\
\hline L. rhamnosus & Bacteraemia & $\begin{array}{l}\text { A 14-year-old girl with acute myeloid leukaemia, bacteraemia disappeared only after } 13 \text { months when } \\
\text { the cytostatic therapy was terminated }\end{array}$ & 314 \\
\hline L. plantarum & Bacteraemia & $\begin{array}{l}\text { A patient (43 years) with a subacute endocarditis due to an immunovasculitis and a bloodstream } \\
\text { infection }\end{array}$ & 307 \\
\hline L. rhamnosus & Septicaemia & A 54-year-old woman with diabetes treated with amoxicillin & 296 \\
\hline L. jensenii & Septicaemia & A 50-year-old woman with obstructive acute renal failure & 297 \\
\hline L. paracasei & $\begin{array}{l}\text { Purpura fulminans associated } \\
\text { with liver abscess }\end{array}$ & Not stated & 323 \\
\hline L. acidophilus & Liver abscess & A 27-year-old man with a 6-month history of NOD2/CARD15-positive Crohn's disease & 324 \\
\hline L. casei & Pneumonia and sepsis & A patient with AIDS because of CD4 lymphocyte depletion & 325 \\
\hline L. rhamnosus & Septicaemia & A patient with a graft in the inferior vena cava & 298 \\
\hline L. gasseri & Septic urinary infection & $\begin{array}{l}\text { A patient (66 years) developed severe urinary stasis due to a concrement in his right ureter, treated with } \\
\text { cefotaxime and amoxicillin }\end{array}$ & 326 \\
\hline L. casei & Bacteraemia & $\begin{array}{l}\text { A } 75 \text {-year-old woman (a heavy dairy consumer)with severe thoracic pain due to dissection of the aortic } \\
\text { arch and ascending aorta and treated with amoxicillin }\end{array}$ & 327 \\
\hline $\begin{array}{l}\text { L. rhamnosus Lcr35 } \\
\text { L. rhamnosus ATCC } \\
53103\end{array}$ & $\begin{array}{l}\text { Meningitis and recurrent episodes } \\
\text { of bacteraemia }\end{array}$ & $\begin{array}{l}\text { A child (10 years) undergoing allogeneic haematopoietic } \\
\text { stem cell transplantation and treated unsuccessfully with clindamycin }\end{array}$ & 320 \\
\hline L. casei & Bacteraemia & An immunocompetent 66-year-old man with a history of fever of unknown origin & 319 \\
\hline L. jensenii & Bacteraemia and pyelonephritis & $\begin{array}{l}\text { A 59-year-old woman with progressed follicular lymphoma, diabetes mellitus type-2 and arterial } \\
\text { hypertension and kidney stone treated with antibiotics }\end{array}$ & 309 \\
\hline L. jensenii & Bacteraemia and endocarditis & A 27-year-old woman with a 20-day history of fever and treated with penicillin and gentamicin & 304 \\
\hline L. rhamnosus & $\begin{array}{l}\text { Catheter-related bloodstream } \\
\text { infections }\end{array}$ & $\begin{array}{l}\text { A 38-year-old woman who underwent allogenic transplantation of haematopoietic stem cells from cord } \\
\text { blood for a large granular lymphocyte leukaemia and initially treated with chemotherapy }\end{array}$ & 328 \\
\hline L. delbrueckii & Pyelonephritis and bacteraemia & $\begin{array}{l}\text { A 68-year-old woman with fever, chills, nausea, and vomiting and ureteral calculus with mild left } \\
\text { hydronephrosis treated with ampicillin }\end{array}$ & 311 \\
\hline L. rhamnosus & Sepsis & $\begin{array}{l}\text { A 24-year-old woman developed sepsis resulting from preoperative administration of probiotics following } \\
\text { an aortic valve replacement }\end{array}$ & 301 \\
\hline L. rhamnosus GG & Bacteraemia & $\begin{array}{l}\text { A 69-year-old man with stage IIIA mantle cell lymphoma and treated with probiotic-enriched yogurt } \\
\text { stopping }\end{array}$ & 329 \\
\hline L. rhamnosus GG & Bacteraemia & $\begin{array}{l}\text { An } 11 \text {-month-old boy with fever and hypoxia and with a history of short bowel syndrome secondary to } \\
\text { resection of approximately } 80 \% \text { of the small intestine }\end{array}$ & 310 \\
\hline L. acidophilus & Sepsis & A 69-year-old man with stage IIIA mantle cell lymphoma & 315 \\
\hline L. rhamnosus GG & Bacteraemia & $\begin{array}{l}\text { A 36-week-gestation male infant with short gut syndrome secondary to congenital intestinal atresia and } \\
\text { volvulus }\end{array}$ & 313 \\
\hline L. rhamnosus GG & Bacteraemia & A 34-week-gestation male infant with gastroschisis & 313 \\
\hline L. rhamnosus & Bacteraemia & A 43-year-old woman with ulcerative colitis & 299 \\
\hline L. paracasei & Endocarditis & $\begin{array}{l}\text { A 77-year-old man with a prostate cancer in remission, hiatal hernia, right hip prosthesis, mitral } \\
\text { insufficiency, hypertension, bipolar disorder, and daily consumer of probiotics }\end{array}$ & 330 \\
\hline
\end{tabular}

impaired insulin sensitivity of insulin target organs, that is, adipose tissue, liver and muscle (type-2 diabetes or diabetes mellitus). ${ }^{277}$ In this context, inflammatory immune responses play a crucial role in the progression of both types of disease. ${ }^{278-280}$ As for type- 2 diabetes, it is generally treated with intestinal $\alpha$-glucosidase inhibitors. ${ }^{281}$ In this regard, Actinoplanes spp have been shown to naturally produce potent $\alpha$-glucosidase inhibitor compounds including acarbose. Panwar and coworkers first isolated and extracted lactobacilli from human infant faecal samples and evaluated their inhibitory activity against intestinal maltase, sucrose, lactase and amylase, all enzymes involved in hydrolysis of carbohydrates. ${ }^{281}$ This study showed that several strains exert powerful inhibitory effects against the aforementioned enzymes and L. rhamnosus reduced glucose excursions in rats during a carbohydrate challenge by inhibiting $\beta$-glucosidase as well as $\alpha$-glucosidase activities. Even if further studies are 
certainly needed, administration of lactobacilli may represent a promising novel therapeutic tool for treatment of diabetes. Clinical studies of lactobacilli showing efficacy for treatment of diabetes have been summarised in table 13 .

\section{Arthritis}

Osteoarthritis, a chronic joint disease characterised by progressive cartilage degeneration, subchondral bone sclerosis, synovial inflammation and osteophyte formation, ${ }^{283}$ mainly affects weightbearing joints such as knees and hips. A chronic inflammatory response occurs in synovial membranes with increased expression of proinflammatory cytokines and mononuclear cell infiltration. ${ }^{284}$ Oral intake of skimmed milk fermented with L. delbrueckii subsp bulgaricus OLL1073R-1 inhibits the development of collagen-induced arthritis in mice. Moreover, a reduced secretion of IFN- $\gamma$ was also observed in these animals. ${ }^{285}$ Moreover, L. casei suppresses experimental rheumatoid arthritis by downregulating Th1-type inflammatory responses ${ }^{286}$ and its coadministration with type-II collagen and glucosamine decreased the expression of various proinflammatory cytokines and matrix metalloproteinases, upregulating anti-inflammatory cytokines. ${ }^{287}$ The immunomodulating activity of lactobacilli in rheumatoid arthritis was also confirmed by a trial on 45 adult men and women affected by this pathology. ${ }^{288}$ Bacillus coagulans GBI-30, 6086, administered for 60 days in addition to standard antiarthritic medications, resulted in an improvement in the Patient Pain Assessment score and statistically significant improvement in Pain Scale with respect to placebo.

\section{Other pathologies}

Lactobacilli have found application for treatment of several other pathologies. For instance, L. plantarum strain K21 that inhibits lipid accumulation in 3T3-L1 preadipocytes, alleviated body weight gain and epididymal fat mass accumulation, reduced plasma leptin levels, decreased cholesterol and triglyceride levels as well as mitigated liver damage in a mouse model of diet-induced obesity. ${ }^{289}$ Antilipidemic effects of lactobacilli were also evaluated along with memory-enhancing activity in aged Fischer 344 rats. $^{290}$ A probiotic mixture of L. plantarum KY1032 and L. curvatus HY7601 was provided once a day for 8 weeks. A significant inhibition of age-dependent increase in blood triglycerides and a reduction in high-density lipoprotein cholesterol was observed. Moreover, the mixture restored age-reduced spontaneous alternation in the Y-maze task and agesuppressed doublecortin and brain derived neurotrophic factor expression. In addition, suppression of p16, p53 and cyclooxygenase-2 expression, phosphorylation of protein kinase $\mathrm{B}$ and mammalian target of rapamycin and activation of nuclear factor $\kappa$-light-chain-enhancer of activated $B$ cells were observed, thus suggesting a therapeutic role of such mixture in ameliorating age-dependent memory deficit and lipidemia in aged subjects. Clinical studies of lactobacilli showing efficacy for treatment of various pathologies have been summarised in table 14.

\section{SIDE EFFECTS OF LACTOBACILLI}

The widespread clinical use of lactobacilli, even for pathologies that are challenging to treat, has highlighted potential translocations or mutations and untoward effects such as sepsis, ${ }^{296-301}$ endocarditis, ${ }^{302-305}$ bacteraemia ${ }^{299}$ 306-319 $^{3}$ and even death. ${ }^{320}$ Evidence regarding lactobacilli side effect profile has been summarised in table 15 .

\section{CONCLUSIONS}

The mammalian gut microbiome interacts with several physiological systems within the host contributing to multiple biological processes. In vitro and in vivo investigations have shown that prolonged probiotic administration induces qualitative and quantitative modifications in complex, well-settled microbial ecosystems through bacteriocin substrate competition and possibly other mechanisms that still need to be acknowledged. Probiotics can modulate the GI tract microbial ecology exerting immunomodulatory effects that are therapeutic at least for treatment of specific pathologies. ${ }^{331}$ Our review takes into account the available clinical and experimental evidence on the use of lactobacilli in order to give an overview of their suitability to be enclosed in well defined updated therapeutic protocols for specific pathologies. A limited number of studies have already tested the hypothesis that lactobacilli could be combined with bifidobacteria or other nutrients, such as fibres, in order to enhance the bioavailability, mucosal adhesion and therapeutic effectiveness of lactobacilli. Further studies are certainly warranted to determine the most effective combinations for treatment of individual pathologies. The claim that pools of lactobacilli could better survive within the gut lumen and even in the colon, and stably integrate within the pre-existing microbiome, has never been proved in terms of dose-effect and risk of sepsis and bacteraemia. We do not have enough information about the long-term genetic stability (with some exceptions such as L. paracasei subsp paracasei $\mathrm{F} 19^{332}{ }^{333}$ ), the antibiotic susceptibility and translocation rate of $L$. strains. ${ }^{334-336}$ Therefore, further investigations are required to fill in this gap. We would also like to point out the increasing interest in lactobacilli used for industrial food fermentation which has reached a high degree of sophistication that could be useful also for medical applications. ${ }^{337}$ For example, various novel biological modifications have been introduced such as the lysostaphin-expressing gene to prevent growth of toxic shock syndrome toxin 1 producing strains of $S$. aureus. ${ }^{338}$

However, since data concerning the safety and genetic stability of lactobacilli is still limited, toxicological studies evaluating the effects of their genetic modification on the homeostasis of the host organism are still required. Ongoing research on the human microbiome composition will likely yield new species of the genus $L$. that might also have therapeutic applications for specific pathologies.

\section{Take home messages}

- Experimental and clinical evidence supports effectiveness of lactobacilli for treatment of several pathological conditions.

- Long-term consumption of lactobacilli induces qualitative and quantitative modifications in the human gastrointestinal microbial ecosystem.

- Pharmacological profile of lactobacilli needs to be further characterised in order to avoid translocation-related risks.

Correction notice Since this paper was published online the author has changed the formatting of tables 2-15, corrected the units in these tables and added italics to gene names throughout the paper.

Handling editor Slade Jensen

Acknowledgements JCMM acknowledges CONACyT for membership.

Contributors All the authors contributed equally to this work. 


\section{Competing interests None declared}

Provenance and peer review Not commissioned; externally peer reviewed.

Open Access This is an Open Access article distributed in accordance with the Creative Commons Attribution Non Commercial (CC BY-NC 4.0) license, which permits others to distribute, remix, adapt, build upon this work non-commercially, and license their derivative works on different terms, provided the original work is properly cited and the use is non-commercial. See: http://creativecommons.org/ licenses/by-nc/4.0/

\section{REFERENCES}

1 Cryan JF, Dinan TG. Mind-altering microorganisms: the impact of the gut microbiota on brain and behaviour. Nat Rev Neurosci 2012;13:701-12.

2 Clarke G, Stilling RM, Kennedy PJ, et al. Minireview: gut microbiota: the neglected endocrine organ. Mol Endocrinol 2014;28:1221-38.

3 El Aidy S, Dinan TG, Cryan JF. Gut microbiota: the conductor in the orchestra of immune-neuroendocrine communication. Clin Ther 2015;37:954-67.

4 Adlerberth I, Wold AE. Establishment of the gut microbiota in Western infants. Acta Paediatr 2009;98:229-38.

5 Chassard C, de Wouters T, Lacroix C. Probiotics tailored to the infant: a window of opportunity. Curr Opin Biotechnol 2014;26:141-7.

6 Samot J, Lebreton J, Badet C. Adherence capacities of oral lactobacilli for potential probiotic purposes. Anaerobe 2011;17:69-72.

7 Sengupta R, Altermann E, Anderson RC, et al. The role of cell surface architecture of lactobacilli in host-microbe interactions in the gastrointestinal tract. Mediators Inflamm 2013;2013:237921.

8 Hawrelak JA, Myers SP. The causes of intestinal dysbiosis: a review. Altern Med Rev 2004;9:180-97.

9 Ouwehand AC, Salminen S, Isolauri E. Probiotics: an overview of beneficial effects Antonie Van Leeuwenhoek 2013;82:279-89.

10 Michail S. The mechanism of action of probiotics. Practic Gastroenterol 2005;2:29-47.

11 Rescigno M. The intestinal epithelial barrier in the control of homeostasis and immunity. Trends Immunol 2011;32:256-64.

12 Polak-Berecka M, Wasko A, Paduch R, et al. The effect of cell surface components on adhesion ability of Lactobacillus rhamnosus. Antonie Van Leeuwenhoek 2014; 106:751-62.

13 Yadav AK, Tyagi A, Kumar A, et al. Adhesion of indigenous Lactobacillus plantarum to gut extracellular matrix and its physicochemical characterization. Arch Microbiol 2015;197:155-64.

14 Fujiwara S, Seto Y, Kimura A, et al. Establishment of orally-administered Lactobacillus gasseri SBT2055SR in the gastrointestinal tract of humans and its influence on intestinal microflora and metabolism. J App/ Microbiol 2001:90:343-52.

15 Hutt P, Koll P, Stsepetova J, et al. Safety and persistence of orally administered human Lactobacillus sp. strains in healthy adults. Benef Microbes 2011;2:79-90.

16 Rosenfeldt V, Pærregaard A, Larsen CN, et al. Faecal recovery, mucosal adhesion, gastrointestinal effects and tolerance of mixed cultures of potential probiotic lactobacilli. Microbi Ecol Health Dis 2011:15:2-9.

17 Jacobsen $C N$, Rosenfeldt Nielsen $V$, Hayford AE, et al. Screening of probiotic activities of forty-seven strains of Lactobacillus spp. by in vitro techniques and evaluation of the colonization ability of five selected strains in humans. App/ Environ Microbiol 1999:65:4949-56.

18 Hughes R, Rowland IR. Metabolic activities of the gut microflora in relation to cancer. Microb Ecol Health Dis 2000;12:179-85.

19 Liong MT. Roles of probiotics and prebiotics in colon cancer prevention: postulated mechanisms and in-vivo evidence. Int J Mol Sci 2008;9:854-63.

20 Heaton KW. The large intestine in nutrition and disease. J $R$ Soc Med 1997;90:410.

21 Goldin BR, Gorbach SL. The effect of milk and lactobacillus feeding on human intestinal bacterial enzyme activity. Am J Clin Nutr 1984;39:756-61.

22 Tannock GW, Munro K, Harmsen HJM, et al. Analysis of the Fecal Microflora of Human Subjects Consuming a Probiotic Product Containing Lactobacillus rhamnosus DR20. App/ Environ Microbiol 2000;66:2578-88.

23 Marteau $\mathrm{P}$, Pochart $\mathrm{P}$, Flourie $\mathrm{B}$, et al. Effect of chronic ingestion of a fermented dairy product containing Lactobacillus acidophilus and Bifidobacterium bifidum on metabolic activities of the colonic flora in humans. Am J Clin Nutr 1990;52:685-8.

24 Goldin BR, Swenson L, Dwyer J, et al. Effect of Diet and Lactobacillus acidophilus Supplements on Human Fecal Bacterial Enzymes. J Nat/ Cancer Inst 1980;64:255-61.

25 Lidbeck A, Nord CE, Gustafsson JA, et al. Lactobacilli, anticarcinogenic activities and human intestinal microflora. Eur J Cancer Prev 1992;1:341-53.

26 Bertkova I, Hijova E, Chmelarova A, et al. The effect of probiotic microorganisms and bioactive compounds on chemically induced carcinogenesis in rats. Neoplasma 2010;57:422-8

27 Van Tassell RL, Kingston DG, Wilkins TD. Metabolism of dietary genotoxins by the human colonic microflora; the fecapentaenes and heterocyclic amines. Mutat Res 1990;238:209-21.

28 Kumar M, Kumar A, Nagpal R, et al. Cancer-preventing attributes of probiotics: an update. Int J Food Sci Nutr 2010;61:473-96.
29 Orrhage K, Sillerstrom E, Gustafsson JA, et al. Binding of mutagenic heterocyclic amines by intestinal and lactic acid bacteria. Mutat Res 1994;311:239-48.

30 Sreekumar 0 , Hosono A. The antimutagenic properties of a polysaccharide produced by Bifidobacterium longum and its cultured milk against some heterocyclic amines. Can J Microbiol 1998;44:1029-36.

31 Sreekumar 0 , Hosono $\mathrm{A}$. The heterocyclic amine binding receptors of Lactobacillus gasseri cells. Mutat Res 1998;421:65-72.

32 Zhang XB, Ohta Y. Antimutagenicity of cell fractions of microorganisms on potent mutagenic pyrolysates. Mutat Res 1993;298:247-53.

33 Sreekumar $\mathrm{O}$, Hosono A. Antimutagenicity and the influence of physical factors in binding Lactobacillus gasseri and Bifidobacterium longum cells to amino acid pyrolysates. J Dairy Sci 1998;81:1508-16.

34 Rhee $\mathrm{CH}$, Park HD. Three glycoproteins with antimutagenic activity identified in Lactobacillus plantarum KLAB21. App/ Environ Microbiol 2001:67:3445-9.

35 Challa $A$, Rao DR, Chawan CB, et al. Bifidobacterium longum and lactulose suppress azoxymethane-induced colonic aberrant crypt foci in rats. Carcinogenesis 1997; 18:517-21.

36 Manning TS, Gibson GR. Microbial-gut interactions in health and disease. Prebiotics. Best Pract Res Clin Gastroenterol 2004;18:287-98.

37 Huycke MM, Gaskins HR. Commensal bacteria, redox stress, and colorectal cancer: mechanisms and models. Exp Biol Med (Maywood) 2004;229:586-97.

38 Sobhani I, Tap J, Roudot-Thoraval F, et al. Microbial dysbiosis in colorectal cancer (CRC) patients. PLOS ONE 2011;6:e16393.

39 Rafter J, Bennett M, Caderni G, et al. Dietary synbiotics reduce cancer risk factors in polypectomized and colon cancer patients. Am J Clin Nutr 2007;85:488-96.

40 O'Mahony L, Feeney M, O'Halloran S, et al. Probiotic impact on microbial flora, inflammation and tumour development in IL-10 knockout mice. Aliment Pharmacol Ther 2001;15:1219-25.

41 Sekine K, Toida T, Saito M, et al. A new morphologically characterized cell wall preparation (whole peptidoglycan) from Bifidobacterium infantis with a higher efficacy on the regression of an established tumor in mice. Cancer Res 1985:45:1300-7.

42 Yokokura T, Kato I, Matsuzaki T, et al. [Antitumor activity of Lactobacillus casei YIT 9018 (LC 9018)-effect of administration route]. Gan To Kagaku Ryoho 1984:11:2427-33.

43 Matsuzaki T, Yokokura T, Azuma I. Anti-tumour activity of Lactobacillus casei on Lewis lung carcinoma and line-10 hepatoma in syngeneic mice and guinea pigs. Cancer Immunol Immunother 1985;20:18-22.

44 Matsuzaki T, Yokokura T, Mutai M. Antitumor effect of intrapleural administration of Lactobacillus casei in mice. Cancer Immunol Immunother 1988;26:209-14.

45 Aso Y, Akaza $\mathrm{H}$, Kotake $\mathrm{T}$, et al. Preventive effect of a Lactobacillus casei preparation on the recurrence of superficial bladder cancer in a double-blind trial. The BLP Study Group. Eur Urol 1995:27:104-9.

46 Aso Y, Akazan H. Prophylactic effect of a Lactobacillus casei preparation on the recurrence of superficial bladder cancer. BLP Study Group. Urol Int 1992;49:125-9.

47 Matsuzaki T. Immunomodulation by treatment with Lactobacillus casei strain Shirota. Int J Food Microbiol 1998;41:133-40.

48 Takagi A, Matsuzaki T, Sato $M$, et al. Inhibitory effect of oral administration of Lactobacillus casei on 3-methylcholanthrene-induced carcinogenesis in mice. Med Microbiol Immunol 1999:188:111-16.

49 Takagi A, Matsuzaki T, Sato M, et al. Enhancement of natural killer cytotoxicity delayed murine carcinogenesis by a probiotic microorganism. Carcinogenesis 2001;22:599-605.

50 Foligne B, Zoumpopoulou G, Dewulf J, et al. A key role of dendritic cells in probiotic functionality. PLOS ONE 2007;2:e313.

51 Yasui $H$, Shida K, Matsuzaki T, et al. Immunomodulatory function of lactic acid bacteria. Antonie Van Leeuwenhoek 1999;76:383-9.

52 Lee JW, Shin JG, Kim EH, et al. Immunomodulatory and antitumor effects in vivo by the cytoplasmic fraction of Lactobacillus casei and Bifidobacterium longum. J Vet Sci 2004;5:41-8.

53 Takagi $\mathrm{A}$, Ikemura $\mathrm{H}$, Matsuzaki $\mathrm{T}$, et al. Relationship between the in vitro response of dendritic cells to Lactobacillus and prevention of tumorigenesis in the mouse. J Gastroentero/ 2008:43:661-9.

54 Matsumoto S, Hara T, Nagaoka M, et al. A component of polysaccharide peptidoglycan complex on Lactobacillus induced an improvement of murine model of inflammatory bowel disease and colitis-associated cancer. Immunology 2009;128(1 Suppl):e170-80.

55 lyer C, Kosters A, Sethi G, et al. Probiotic Lactobacillus reuteri promotes TNF-induced apoptosis in human myeloid leukemia-derived cells by modulation of NF-kappaB and MAPK signalling. Cell Microbiol 2008;10:1442-52.

56 Otte JM, Mahjurian-Namari R, Brand $S$, et al. Probiotics regulate the expression of COX-2 in intestinal epithelial cells. Nutr Cancer 2009:61:103-13.

57 Le Leu RK, Brown IL, Hu Y, et al. A synbiotic combination of resistant starch and Bifidobacterium lactis facilitates apoptotic deletion of carcinogen-damaged cells in rat colon. J Nutr 2005;135:996-1001. 
58 Sadeghi-Aliabadi H, Mohammadi F, Fazeli $\mathrm{H}$, et al. Effects of Lactobacillus plantarum A7 with probiotic potential on colon cancer and normal cells proliferation in comparison with a commercial strain. Iran J Basic Med Sci 2014;17:815-19.

59 Baricault L, Denariaz G, Houri JJ, et al. Use of HT-29, a cultured human colon cancer cell line, to study the effect of fermented milks on colon cancer cell growth and differentiation. Carcinogenesis 1995;16:245-52.

60 Grimoud J, Durand H, de Souza S, et al. In vitro screening of probiotics and synbiotics according to anti-inflammatory and anti-proliferative effects. Int J Food Microbiol 2010;144:42-50.

61 Singh J, Rivenson A, Tomita M, et al. Bifidobacterium longum, a lactic acid-producing intestinal bacterium inhibits colon cancer and modulates the intermediate biomarkers of colon carcinogenesis. Carcinogenesis 1997;18: $833-41$.

62 Topping DL, Clifton PM. Short-chain fatty acids and human colonic function: roles of resistant starch and nonstarch polysaccharides. Physiol Rev 2001;81:1031-64.

63 Whitehead RH, Young GP, Bhathal PS. Effects of short chain fatty acids on a new human colon carcinoma cell line (LIM1215). Gut 1986;27:1457-63.

64 Liew C, Schut HA, Chin SF, et al. Protection of conjugated linoleic acids against 2-amino-3- methylimidazo[4,5-f]quinoline-induced colon carcinogenesis in the F344 rat: a study of inhibitory mechanisms. Carcinogenesis 1995;16:3037-43.

65 Clausen MR, Bonnen H, Mortensen PB. Colonic fermentation of dietary fibre to short chain fatty acids in patients with adenomatous polyps and colonic cancer. Gut 1991;32:923-8.

66 Walker AR, Walker BF, Walker AJ. Faecal pH, dietary fibre intake, and proneness to colon cancer in four South African populations. Br I Cancer 1986;53:489-95.

67 Ohkawara S, Furuya H, Nagashima K, et al. Oral administration of butyrivibrio fibrisolvens, a butyrate-producing bacterium, decreases the formation of aberrant crypt foci in the colon and rectum of mice. J Nutr 2005;135:2878-83.

68 Lan A, Lagadic-Gossmann D, Lemaire C, et al. Acidic extracellular pH shifts colorectal cancer cell death from apoptosis to necrosis upon exposure to propionate and acetate, major end-products of the human probiotic propionibacteria. Apoptosis 2007;12:573-91.

69 Jan G, Belzacq AS, Haouzi D, et al. Propionibacteria induce apoptosis of colorectal carcinoma cells via short-chain fatty acids acting on mitochondria. Cell Death Differ 2002;9:179-88.

70 Borowicki A, Michelmann A, Stein K, et al. Fermented wheat aleurone enriched with probiotic strains $L G G$ and Bb12 modulates markers of tumor progression in human colon cells. Nutr Cancer 2011;63:151-60.

71 Evans NP, Misyak SA, Schmelz EM, et al. Conjugated linoleic acid ameliorates inflammation-induced colorectal cancer in mice through activation of PPARgamma. J Nutr 2010;140:515-21.

$72 \mathrm{Kim} \mathrm{KH}$, Park HS. Dietary supplementation of conjugated linoleic acid reduces colon tumor incidence in DMH-treated rats by increasing apoptosis with modulation of biomarkers. Nutrition 2003;19:772-7.

73 Rao CV, Sanders ME, Indranie C, et al. Prevention of colonic preneoplastic lesions by the probiotic Lactobacillus acidophilus NCFMTM in F344 rats. Int I Oncol 1999; 14:939-44.

74 Yasutake N, Matsuzaki T, Kimura K, et al. The role of tumor necrosis factor (TNF)-alpha in the antitumor effect of intrapleural injection of Lactobacillus case strain Shirota in mice. Med Microbiol Immunol 1999:188:9-14.

75 McIntosh GH, Royle PJ, Playne MJ. A probiotic strain of L. acidophilus reduces DMH-induced large intestinal tumors in male Sprague-Dawley rats. Nutr Cancer 1999:35:153-9.

76 Horinaka M, Yoshida T, Kishi A, et al. Lactobacillus strains induce TRAIL production and facilitate natural killer activity against cancer cells. FEBS Lett 2010;584:577-82

77 Baldwin C, Millette M, Oth D, et al. Probiotic Lactobacillus acidophilus and L. casei mix sensitize colorectal tumoral cells to 5 -fluorouracil-induced apoptosis. Nutr Cancer 2010;62:371-8.

78 El-Nezami HS, Polychronaki NN, Ma J, et al. Probiotic supplementation reduces a biomarker for increased risk of liver cancer in young men from Southern China. Am J Clin Nutr 2006:83:1199-203.

79 Zhang JW, Du P, Gao J, et al. Preoperative probiotics decrease postoperative infectious complications of colorectal cancer. Am J Med Sci 2012;343:199-205.

80 Ohigashi $S$, Hoshino $Y$, Ohde $S$, et al. Functional outcome, quality of life, and efficacy of probiotics in postoperative patients with colorectal cancer. Surg Today 2011:41:1200-6.

81 Vasama M, Kumar $\mathrm{H}$, Salminen $\mathrm{S}$, et al. Removal of paralytic shellfish toxins by probiotic lactic acid bacteria. Toxins (Basel) 2014;6:2127-36.

82 Nowak A, Kuberski S, Libudzisz Z. Probiotic lactic acid bacteria detoxify N-nitrosodimethylamine. Food Addit Contam Part A Chem Anal Control Expo Risk Assess 2014;31:1678-87.

83 Mechoud MA, Juarez GE, de Valdez GF, et al. Lactobacillus reuteri CRL 1098 and Lactobacillus acidophilus CRL 1014 differently reduce in vitro immunotoxic effect induced by Ochratoxin A. Food Chem Toxicol 2012;50:4310-15.
84 Petzinger $\mathrm{E}$, Ziegler $\mathrm{K}$. Ochratoxin A from a toxicological perspective. J Vet Pharmacol Ther 2000;23:91-8.

85 Skopinska E, Lachowicz D, Wultanska D, et al. [Assessment of antagonistic activity in vitro Lactobacillus spp. strains againts Clostridum difficile strains isolated from gastrointestinal tract of patients hospitalized in three hospitals in region Mazovia]. Med Dosw Mikrobiol 2012:64:109-14.

86 Li J, Wang W, Xu SX, et al. Lactobacillus reuteri-produced cyclic dipeptides quench agr-mediated expression of toxic shock syndrome toxin-1 in staphylococci. Proc Natl Acad Sci USA 2011;108:3360-5.

87 Fei YT, Liu DM, Luo TH, et al. Molecular characterization of Lactobacillus plantarum DMDL 9010,a strain with efficient nitrite degradation capacity. PLOS ONE 2014;9:e113792.

88 Satarug S, Garrett SH, Sens MA, et al. Cadmium, environmental exposure, and health outcomes. Environ Health Perspect 2010;118:182-90.

89 Gerbino E, Carasi P, Tymczyszyn EE, et al. Removal of cadmium by Lactobacillus kefir as a protective tool against toxicity. J Dairy Res 2014;81:280-7.

90 Witkin SS. The vaginal microbiome, vaginal anti-microbial defence mechanisms and the clinical challenge of reducing infection-related preterm birth. BJOG 2015;122:213-18.

91 Liu H, Gao Y, Yu LR, et al. Inhibition of Staphylococcus aureus by lysostaphin-expressing Lactobacillus plantarum WCFS1 in a modified genital tract secretion medium. Appl Environ Microbiol 2011:77:8500-8.

92 Kaewsrichan J, Peeyananjarassri K, Kongprasertkit J. Selection and identification of anaerobic lactobacilli producing inhibitory compounds against vaginal pathogens. FEMS Immunol Med Microbiol 2006;48:75-83.

93 Graver MA, Wade JJ. Growth and acidification by vaginal lactobacilli in anaerobic liquid medium over the pH range 5.5-8.0. J Bacteriol Parasitol 2010;1:1-3.

94 Atassi F, Brassart D, Grob P, et al. Lactobacillus strains isolated from the vaginal microbiota of healthy women inhibit Prevotella bivia and Gardnerella vaginalis in coculture and cell culture. FEMS Immunol Med Microbiol 2006;48:424-32.

95 Pashaian MM, Oganesian GG. [Isolation and characterization of vaginal lactobacilli producing hydrogen peroxide]. Zh Mikrobiol Epidemiol Immunobiol 2011:90-3.

96 Lazarenko L, Babenko L, Sichel LS, et al. Antagonistic action of lactobacilli and bifidobacteria in relation to staphylococcus aureus and their influence on the immune response in cases of intravaginal staphylococcosis in mice. Probiotics Antimicrob Proteins 2012:4:78-89.

97 De Seta F, Parazzini F, De Leo R, et al. Lactobacillus plantarum P17630 for preventing Candida vaginitis recurrence: a retrospective comparative study. Eur J Obstet Gynecol Reprod Biol 2014;182:136-9.

98 Sobel JD. Recurrent vulvovaginal candidiasis. A prospective study of the efficacy of maintenance ketoconazole therapy. N Engl J Med 1986;315:1455-8.

99 Winn HN. Group B streptococcus infection in pregnancy. Clin Perinatol 2007;34:387-92.

100 De Gregorio PR, Juarez Tomas MS, Leccese Terraf MC, et al. Preventive effect of Lactobacillus reuteri CRL1324 on Group B Streptococcus vaginal colonization in an experimental mouse model. J Appl Microbiol 2015;118:1034-47.

101 Baker CJ, Edwards MS. Group B streptococcal infections. In: Remington JS, Klein JO, eds. Infectious diseases of the fetus and newborn infant. Philadelphia: W.B. Saunders Co., 2001:1091-156.

102 Reid G, Charbonneau D, Erb J, et al. Oral use of Lactobacillus rhamnosus GR-1 and L. fermentum RC-14 significantly alters vaginal flora: randomized, placebo-controlled trial in 64 healthy women. FEMS Immunol Med Microbiol 2003;35:131-4.

103 Di Pierro F, Di Paola G, Risso P. Role of a medical device for intra-vaginal use in improving the quality of the colposcopic examination and the anatomical/ pathological reading of the cytological test and biopsy. Acta Biomed 2014;85:121-6.

104 Ehrstrom S, Daroczy K, Rylander E, et al. Lactic acid bacteria colonization and clinical outcome after probiotic supplementation in conventionally treated bacterial vaginosis and vulvovaginal candidiasis. Microbes Infect 2010;12:691-9.

105 Murina F, Graziottin A, Vicariotto F, et al. Can Lactobacillus fermentum LF10 and Lactobacillus acidophilus LA02 in a slow-release vaginal product be useful for prevention of recurrent vulvovaginal candidiasis?: a clinical study. J Clin Gastroenterol 2014;48(Suppl 1):S102-5.

106 Vicariotto F, Mogna L, Del Piano M. Effectiveness of the two microorganisms Lactobacillus fermentum LF15 and Lactobacillus plantarum LP01, formulated in slow-release vaginal tablets, in women affected by bacterial vaginosis: a pilot study. I Clin Gastroenterol 2014;48(Suppl 1):S106-12.

107 Mastromarino P, Macchia S, Meggiorini L, et al. Effectiveness of Lactobacillus-containing vaginal tablets in the treatment of symptomatic bacterial vaginosis. Clin Microbiol Infect 2009;15:67-74.

108 Petricevic L, Unger FM, Viernstein $\mathrm{H}$, et al. Randomized, double-blind, placebo-controlled study of oral lactobacilli to improve the vaginal flora of postmenopausal women. Eur J Obstet Gynecol Reprod Biol 2008;141:54-7.

109 Larsson PG, Stray-Pedersen B, Ryttig KR, et al. Human lactobacilli as supplementation of clindamycin to patients with bacterial vaginosis reduce the 
recurrence rate; a 6-month, double-blind, randomized, placebo-controlled study. BMC Womens Health 2008;8:3.

110 De Smet I, De Boever P, Verstraete W. Cholesterol lowering in pigs through enhanced bacterial bile salt hydrolase activity. Br J Nutr 1998;79:185-94.

111 Kumar R, Grover S, Batish VK. Hypocholesterolaemic effect of dietary inclusion of two putative probiotic bile salt hydrolase-producing Lactobacillus plantarum strains in Sprague-Dawley rats. Br J Nutr 2011;105:561-73.

112 Liong MT, Shah NP. Production of organic acids from fermentation of mannitol, fructooligosaccharide and inulin by a cholesterol removing Lactobacillus acidophilus strain. J App/ Microbiol 2005;99:783-93.

113 Anandharaj M, Sivasankari B. Isolation of potential probiotic Lactobacillus oris HMI68 from mother's milk with cholesterol-reducing property. J Biosci Bioeng 2014;118:153-9.

114 Tomaro-Duchesneau C, Jones ML, Shah D, et al. Cholesterol assimilation by Lactobacillus probiotic bacteria: an in vitro investigation. BioMed Res Int 2014; $2014: 380316$.

115 Tomaro-Duchesneau C, Saha S, Malhotra M, et al. Probiotic ferulic acid esterase active lactobacillus fermentum NCIMB 5221 APA microcapsules for oral delivery: preparation and in vitro characterization. Pharmaceuticals (Basel) 2012:5: 236-48.

116 Kim HK, Jeong TS, Lee MK, et al. Lipid-lowering efficacy of hesperetin metabolites in high-cholesterol fed rats. Clin Chim Acta Clinica chimica 2003;327:129-37.

117 Anandharaj M, Sivasankari B, Santhanakaruppu R, et al. Determining the probiotic potential of cholesterol-reducing Lactobacillus and Weissella strains isolated from gherkins (fermented cucumber) and south Indian fermented koozh. Res Microbiol 2015;166:428-39.

118 Fuentes MC, Lajo T, Carrion JM, et al. Cholesterol-lowering efficacy of Lactobacillus plantarum CECT 7527, 7528 and 7529 in hypercholesterolaemic adults. Br J Nutr 2013;109:1866-72.

119 Anderson JW, Gilliland SE. Effect of Fermented Milk (Yogurt) Containing Lactobacillus Acidophilus L1 on Serum Cholesterol in Hypercholesterolemic Humans. J Am Coll Nutr 1999:18:43-50.

120 Jones ML, Martoni CJ, Parent M, et al. Cholesterol-lowering efficacy of a microencapsulated bile salt hydrolase-active Lactobacillus reuteri NCIMB 30242 yoghurt formulation in hypercholesterolaemic adults. Br J Nutr 2012;107:1505-13.

121 Ataie-Jafari A, Larijani B, Alavi Majd $\mathrm{H}$, et al. Cholesterol-lowering effect of probiotic yogurt in comparison with ordinary yogurt in mildly to moderately hypercholesterolemic subjects. Ann Nutr Metab 2009;54:22-7.

122 Uskova MA, Kravchenko LV. [Antioxidant properties of lactic acid bacteriaprobiotic and yogurt strains]. Vopr Pitan 2009;78:18-23.

123 Sun J, Hu XL, Le GW, et al. Lactobacilli prevent hydroxy radical production and inhibit Escherichia coli and Enterococcus growth in system mimicking colon fermentation. Lett Appl Microbiol 2010;50:264-9.

124 Li S, Zhao Y, Zhang L, et al. Antioxidant activity of Lactobacillus plantarum strains isolated from traditional Chinese fermented foods. Food Chem 2012;135:1914-19.

125 Amaretti A, di Nunzio M, Pompei A, et al. Antioxidant properties of potentially probiotic bacteria: in vitro and in vivo activities. App/ Microbiol Biotechnol 2013;97:809-17.

126 de Waard R, Garssen J, Bokken GC, et al. Antagonistic activity of Lactobacillus casei strain shirota against gastrointestinal Listeria monocytogenes infection in rats. Int J Food Microbiol 2002;73:93-100.

127 Bredholt S, Nesbakken T, Holck A. Protective cultures inhibit growth of Listeria monocytogenes and Escherichia coli 0157:H7 in cooked, sliced, vacuum- and gas-packaged meat. Int J Food Microbiol 1999;53:43-52.

128 Forestier C, De Champs C, Vatoux C, et al. Probiotic activities of Lactobacillus casei rhamnosus: in vitro adherence to intestinal cells and antimicrobial properties. Res Microbiol 2001;152:167-73.

129 Michail S, Abernathy F. Lactobacillus plantarum reduces the in vitro secretory response of intestinal epithelial cells to enteropathogenic Escherichia coli infection. J Pediatr Gastroenterol Nutr 2002;35:350-5.

130 Dicks LM, ten Doeschate K. Enterococcus mundtii ST4SA and Lactobacillus plantarum 423 alleviated symptoms of Salmonella infection, as determined in Wistar rats challenged with Salmonella enterica serovar Typhimurium. Curr Microbiol 2010;61:184-9.

131 Shukla G, Devi P, Sehgal R. Effect of Lactobacillus casei as a probiotic on modulation of giardiasis. Dig Dis Sci 2008:53:2671-9.

132 Coconnier MH, Lievin V, Lorrot M, et al. Antagonistic activity of Lactobacillus acidophilus LB against intracellular Salmonella enterica serovar Typhimurium infecting human enterocyte-like Caco-2/TC-7 cells. App/ Environ Microbiol 2000:66:1152-7.

133 Shokryazdan P, Sieo CC, Kalavathy R, et al. Probiotic potential of Lactobacillus strains with antimicrobial activity against some human pathogenic strains. BioMed Res Int 2014;2014:927268.

134 Meira SM, Helfer VE, Velho RV, et al. Probiotic potential of Lactobacillus spp. isolated from Brazilian regional ovine cheese. J Dairy Res 2012; 79:119-27.
135 Kang MS, Oh JS, Lee $\mathrm{HC}$, et al. Inhibitory effect of Lactobacillus reuteri on periodontopathic and cariogenic. J Microbiol 2011;49:193-9.

136 Guo J, Mauch A, Galle S, et al. Inhibition of growth of Trichophyton tonsurans by Lactobacillus reuteri. J App/ Microbiol 2011;111:474-83.

137 Zhang Y, Zhang L, Du M, et al. Antimicrobial activity against Shigella sonnei and probiotic properties of wild lactobacilli from fermented food. Microbiol Res 2011;167:27-31.

138 Asahara T, Shimizu K, Takada T, et al. Protective effect of Lactobacillus casei strain Shirota against lethal infection with multi-drug resistant Salmonella enterica serovar Typhimurium DT104 in mice. J Appl Microbiol 2011;110:163-73.

139 Nielsen DS, Cho GS, Hanak A, et al. The effect of bacteriocin-producing Lactobacillus plantarum strains on the intracellular pH of sessile and planktonic Listeria monocytogenes single cells. Int J Food Microbiol 2010;141(Suppl 1): S53-9.

140 Bernardeau M, Gueguen M, Smith DG, et al. In vitro antagonistic activities of Lactobacillus spp. against Brachyspira hyodysenteriae and Brachyspira pilosicoli. Vet Microbiol 2009;138:184-90.

141 Lavermicocca P, Valerio F, Lonigro SL, et al. Antagonistic activity of potential probiotic Lactobacilli against the ureolytic pathogen Yersinia enterocolitica. Curr Microbiol 2008;56:175-81.

142 Coman MM, Verdenelli MC, Cecchini C, et al. In vitro evaluation of antimicrobial activity of Lactobacillus rhamnosus IMC 501((R)), Lactobacillus paracasei IMC 502((R)) and SYNBIO((R)) against pathogens. J App/ Microbiol 2014;117: $518-27$.

143 Bolla PA, Carasi P, Serradell Mde L, et al. Kefir-isolated Lactococcus lactis subsp. lactis inhibits the cytotoxic effect of Clostridium difficile in vitro. J Dairy Res 2013;80:96-102.

144 Zhang D, Li R, Li J. Lactobacillus reuteri ATCC 55730 and L22 display probiotic potential in vitro and protect against Salmonella-induced pullorum disease in a chick model of infection. Res Vet Sci 2012:93:366-73.

145 Martin R, Olivares M, Marin ML, et al. Characterization of a reuterin-producing Lactobacillus coryniformis strain isolated from a goat's milk cheese. Int I Food Microbiol 2005; 104:267-77.

146 Aween MM, Hassan Z, Muhialdin BJ, et al. Antibacterial activity of Lactobacillus acidophilus strains isolated from honey marketed in Malaysia against selected multiple antibiotic resistant (MAR) Gram-positive bacteria. J Food Sci 2012;77: M364-71.

147 Cadieux PA, Burton J, Devillard E, et al. Lactobacillus by-products inhibit the growth and virulence of uropathogenic Escherichia coli. J Physiol Pharmacol 2009;60(Suppl 6):13-8

148 Teanpaisan R, Piwat S, Dahlen G. Inhibitory effect of oral Lactobacillus against ora pathogens. Lett App/ Microbiol 2011;53:452-9.

149 Mappley LJ, Tchorzewska MA, Cooley WA, et al. Lactobacilli antagonize the growth, motility, and adherence of Brachyspira pilosicoli: a potential intervention against avian intestinal spirochetosis. App/ Environ Microbiol 2011;77:5402-11.

150 Jebur M. Therapeutic efficacy of Lactobacillus acidophilus against bacterial isolates from burn wounds. N Am J Med Sci 2010;2:586-91.

151 Asahara T, Nomoto K, Watanuki M, et al. Antimicrobial activity of intraurethrally administered probiotic Lactobacillus casei in a murine model of Escherichia coli urinary tract infection. Antimicrob Agents Chemother 2001;45:1751-60.

152 Pridmore RD, Pittet AC, Praplan F, et al. Hydrogen peroxide production by Lactobacillus johnsonii NCC 533 and its role in anti-Salmonella activity. FEMS Microbiol Lett 2008;283:210-15.

153 Castillo NA, de Moreno de LeBlanc A, C MG, Perdigon G. Comparative study of the protective capacity against Salmonella infection between probiotic and nonprobiotic Lactobacilli. J App/ Microbiol 2013;114:861-76.

154 Huang SH, He L, Zhou Y, et al. Lactobacillus rhamnosus GG Suppresses Meningitic E. coli K1 Penetration across Human Intestinal Epithelial Cells In Vitro and Protects Neonatal Rats against Experimental Hematogenous Meningitis. Int J Microbiol 2009;2009:647862.

155 Winkelstroter LK, De Martinis EC. In vitro protective effect of lactic acid bacteria on Listeria monocytogenes adhesion and invasion of Caco-2 cells. Benef Microbes 2015:6:535-42.

156 Alemka A, Clyne M, Shanahan F, et al. Probiotic colonization of the adherent mucus layer of HT29MTXE12 cells attenuates Campylobacter jejuni virulence properties. Infect Immun 2010;78:2812-22.

157 Gudina EJ, Rocha V, Teixeira JA, et al. Antimicrobial and antiadhesive properties of a biosurfactant isolated from Lactobacillus paracasei ssp. paracasei A20. Lett Appl Microbiol 2010;50:419-24.

158 Walencka E, Rozalska S, Sadowska B, et al. The influence of Lactobacillus acidophilus-derived surfactants on staphylococcal adhesion and biofilm formation. Folia Microbiol (Praha) 2008:53:61-6.

159 Sambanthamoorthy K, Feng X, Patel R, et al. Antimicrobial and antibiofilm potential of biosurfactants isolated from lactobacilli against multi-drug-resistant pathogens. BMC Microbiol 2014;14:197.

160 Lim SM, Ahn DH. Factors affecting adhesion of lactic acid bacteria to Caco-2 cells and inhibitory effect on infection of Salmonella typhimurium. J Microbiol Biotechnol 2012;22:1731-9. 
161 Eom JS, Song J, Choi HS. Protective Effects of a Novel Probiotic Strain of Lactobacillus plantarum JSA22 from Traditional Fermented Soybean Food Against Infection by Salmonella enterica Serovar Typhimurium. J Microbiol Biotechnol 2015;25:479-91.

162 Bertaux C, Daelemans D, Meertens L, et al. Entry of hepatitis C virus and human immunodeficiency virus is selectively inhibited by carbohydrate-binding agents but not by polyanions. Virology 2007;366:40-50.

163 Myer L, Denny L, Telerant R, et al. Bacterial vaginosis and susceptibility to HIV infection in South African women: a nested case-control study. J Infect Dis 2005;192:1372-80

164 Watts DH, Fazzari M, Minkoff $\mathrm{H}$, et al. Effects of bacterial vaginosis and other genital infections on the natural history of human papillomavirus infection in HIV-1-infected and high-risk HIV-1-uninfected women. J Infect Dis 2005;191:1129-39.

165 Cherpes TL, Meyn LA, Krohn MA, et al. Association between acquisition of herpes simplex virus type 2 in women and bacterial vaginosis. Clin Infect Dis 2003:37:319-25.

166 Lehours P, Yilmaz O. Epidemiology of Helicobacter pylori infection. Helicobacter 2007;12(Suppl 1):1-3.

167 Chen X, Liu XM, Tian F, et al. Antagonistic activities of lactobacilli against Helicobacter pylori growth and infection in human gastric epithelial cells. J Food Sci 2012;77:M9-14.

168 Fujimura S, Watanabe A, Kimura K, et al. Probiotic mechanism of Lactobacillus gasseri OLL2716 strain against Helicobacter pylori. J Clin Microbio/ 2012:50: $1134-6$.

169 Mukai T, Asasaka T, Sato E, et al. Inhibition of binding of Helicobacter pylori to the glycolipid receptors by probiotic Lactobacillus reuteri. FEMS Immunol Med Microbiol 2002;32:105-10.

170 Hatakka K, Holma R, El-Nezami H, et al. The influence of Lactobacillus rhamnosus LC705 together with Propionibacterium freudenreichii ssp. shermanii JS on potentially carcinogenic bacterial activity in human colon. Int I Food Microbiol 2008:128:406-10.

171 Boyanova L, Stephanova-Kondratenko M, Mitov I. Anti-Helicobacter pylori activity of Lactobacillus delbrueckii subsp. bulgaricus strains: preliminary report. Lett Appl Microbiol 2009; 48:579-84.

172 Coconnier MH, Lievin V, Hemery E, et al. Antagonistic activity against Helicobacter infection in vitro and in vivo by the human Lactobacillus acidophilus strain LB. Appl Environ Microbiol 1998;64:4573-80.

173 Cruchet S, Obregon MC, Salazar G, et al. Effect of the ingestion of a dietary product containing Lactobacillus johnsonii La1 on Helicobacter pylori colonization in children. Nutrition 2003;19:716-21.

174 Sakamoto I, Igarashi M, Kimura K, et al. Suppressive effect of Lactobacillus gasseri OLL 2716 (LG21) on Helicobacter pylori infection in humans. J Antimicrob Chemother 2001;47:709-10.

175 Wang KY, Li SN, Liu CS, et al. Effects of ingesting Lactobacillus- and Bifidobacterium-containing yogurt in subjects with colonized Helicobacter pylori. Am J Clin Nutr 2004;80:737-41.

176 Aiba Y, Nakano Y, Koga Y, et al. A highly acid-resistant novel strain of Lactobacillus johnsonii No. 1088 has antibacterial activity, including that against Helicobacter pylori, and inhibits gastrin-mediated acid production in mice. Microbiologyopen 2015;4:465-74

177 Compare D, Rocco A, Sgamato C, et al. Lactobacillus paracasei F19 versus placebo for the prevention of proton pump inhibitor-induced bowel symptoms: a randomized clinical trial. Dig Liver Dis 2015; 47:273-9.

178 Leonard J, Marshall JK, Moayyedi P. Systematic review of the risk of enteric infection in patients taking acid suppression. Am I Gastroenterol 2007;102:2047-56; quiz 57.

179 Williams C, McColl KE. Review article: proton pump inhibitors and bacterial overgrowth. Aliment Pharmacol Ther 2006;23:3-10.

180 Sanduleanu S, Jonkers D, de Bruine A, et al. Changes in gastric mucosa and luminal environment during acid-suppressive therapy: a review in depth. Dig Liver Dis 2001;33:707-19.

181 Crittenden R, Saarela M, Mättö J, et al. Lactobacillus paracasei subsp. paracasei F19: Survival, Ecology and Safety in the Human Intestinal Tract-A Survey of Feeding Studies within the PROBDEMO Project. Microbial Ecology Health Dis 2002;14:22-6.

182 Tursi A, Brandimarte G, Giorgetti GM, et al. Effect of Lactobacillus casei supplementation on the effectiveness and tolerability of a new second-line 10-day quadruple therapy after failure of a first attempt to cure Helicobacter pylori infection. Med Scie Monit 2004;10:Cr662-6.

183 Sykora J, Valeckova K, Amlerova J, et al. Effects of a specially designed fermented milk product containing probiotic Lactobacillus casei DN-114 001 and the eradication of $\mathrm{H}$. pylori in children: a prospective randomized double-blind study. J Clin Gastroenterol 2005;39:692-8.

184 Sheu BS, Wu JJ, Lo CY, et al. Impact of supplement with Lactobacillus- and Bifidobacterium-containing yogurt on triple therapy for Helicobacter pylori eradication. Aliment Pharmacol Ther 2002;16:1669-75.
185 Lionetti E, Miniello VL, Castellaneta SP, et al. Lactobacillus reuteri therapy to reduce side-effects during anti-Helicobacter pylori treatment in children: a randomized placebo controlled trial. Aliment Pharmacol Ther 2006;24:1461-8.

$186 \mathrm{Kim}$ MN, Kim N, Lee SH, et al. The effects of probiotics on PPI-triple therapy for Helicobacter pylori eradication. Helicobacter 2008;13:261-8.

187 Francavilla R, Polimeno L, Demichina A, et al. Lactobacillus reuteri strain combination in Helicobacter pylori infection: a randomized, double-blind, placebo-controlled study. J Clin Gastroenterol 2014;48:407-13.

188 Deguchi R, Nakaminami H, Rimbara E, et al. Effect of pretreatment with Lactobacillus gasseri OLL2716 on first-line Helicobacter pylori eradication therapy. J Gastroenterol Hepatol 2012;27:888-92.

189 Linsalata M, Russo F, Berloco P, et al. The influence of Lactobacillus brevis on ornithine decarboxylase activity and polyamine profiles in Helicobacter pylori-infected gastric mucosa. Helicobacter 2004;9:165-72.

190 Di Cerbo A, Pezzuto F, Palmieri L, et al. Clinical and experimental use of probiotic formulations for management of end-stage renal disease: an update. Int Urol Nephrol 2013;5:1569-76.

191 Ranganathan N, Ranganathan P, Friedman EA, et al. Pilot study of probiotic dietary supplementation for promoting healthy kidney function in patients with chronic kidney disease. Adv Ther 2010;27:634-47.

192 Cook AR. Urease activity in the rumen of sheep and the isolation of ureolytic bacteria. J Gen Microbiol 1976;92:32-48.

193 Capozzi V, Russo P, Ladero V, et al. Biogenic amines degradation by lactobacillus plantarum: toward a potential application in wine. Front Microbiol 2012;3:122

194 Herrero-Fresno A, Martinez N, Sanchez-Llana E, et al. Lactobacillus casei strains isolated from cheese reduce biogenic amine accumulation in an experimental model. Int J Food Microbiol 2012;157:297-304.

195 Murphy C, Murphy S, O'Brien F, et al. Metabolic activity of probiotics-oxalate degradation. Vet Microbiol 2009;136:100-7.

196 Mogna L, Pane M, Nicola S, et al. Screening of different probiotic strains for their in vitro ability to metabolise oxalates: any prospective use in humans? I Clin Gastroenterol 2014;48(Suppl 1):S91-5.

197 Campieri C, Campieri M, Bertuzzi V, et al. Reduction of oxaluria after an oral course of lactic acid bacteria at high concentration. Kidney Int 2001;60:1097-105.

198 Freedman GR. Breast-feeding - a guide for the medical profession. J R Coll Gen Pract 1981;31:126

199 Delgado S, Arroyo R, Jimenez E, et al. Staphylococcus epidermidis strains isolated from breast milk of women suffering infectious mastitis: potential virulence traits and resistance to antibiotics. BMC Microbiol 2009;9:82.

200 Foxman B, D'Arcy H, Gillespie B, et al. Lactation mastitis: occurrence and medical management among 946 breastfeeding women in the United States. Am J Epidemiol 2002;155:103-14.

201 WHO. Mastitis: causes and management. 2000 /entity/maternal_child_adolescent/ documents/fch_cah_00_13/en/index.html

202 Arroyo R, Martin V, Maldonado A, et al. Treatment of infectious mastitis during lactation: antibiotics versus oral administration of Lactobacilli isolated from breast milk. Clin Infect Dis 2010;50:1551-8.

203 Jimenez E, Fernandez L, Maldonado A, et al. Oral administration of Lactobacillus strains isolated from breast milk as an alternative for the treatment of infectious mastitis during lactation. Appl Environ Microbiol 2008;74:4650-5.

204 Tuomola E, Crittenden R, Playne M, et al. Quality assurance criteria for probiotic bacteria. Am J Clin Nutr 2001;73(2 Suppl):393s-8s.

205 Iwabuchi N, Yonezawa S, Odamaki T, et al. Immunomodulating and anti-infective effects of a novel strain of Lactobacillus paracasei that strongly induces interleukin-12. FEMS Immunol Med Microbiol 2012;66:230-9.

206 Soltan Dallal MM, Yazdi MH, Holakuyee M, et al. Lactobacillus casei ssp.casei induced Th1 cytokine profile and natural killer cells activity in invasive ductal carcinoma bearing mice. Iran J Allergy Asthma Immunol 2012;11:183-9.

207 Yesilova Y, Calka O, Akdeniz N, et al. Effect of probiotics on the treatment of children with atopic dermatitis. Ann Dermatol 2012;24:189-93.

208 Taverniti V, Minuzzo M, Arioli S, et al. In vitro functional and immunomodulatory properties of the Lactobacillus helveticus MIMLh5-Streptococcus salivarius ST3 association that are relevant to the development of a pharyngeal probiotic product. Appl Environ Microbiol 2012;78:4209-16.

209 Ghadimi D, de Vrese M, Heller KJ, et al. Lactic acid bacteria enhance autophagic ability of mononuclear phagocytes by increasing Th1 autophagy-promoting cytokine (IFN-gamma) and nitric oxide (NO) levels and reducing Th2 autophagy-restraining cytokines (IL-4 and IL-13) in response to Mycobacterium tuberculosis antigen. Int Immunopharmacol 2010;10:694-706.

210 Ivory K, Chambers SJ, Pin C, et al. Oral delivery of Lactobacillus casei Shirota modifies allergen-induced immune responses in allergic rhinitis. Clin Exp Allergy 2008;38:1282-9.

211 Osman N, Adawi D, Ahrne S, et al. Endotoxin- and D-galactosamine-induced liver injury improved by the administration of Lactobacillus, Bifidobacterium and blueberry. Dig Liver Dis 2007;39:849-56.

212 Machairas N, Pistiki A, Droggiti DI, et al. Pre-treatment with probiotics prolongs survival after experimental infection by multidrug-resistant Pseudomonas 
aeruginosa in rodents: an effect on sepsis-induced immunosuppression. Int J Antimicrob Agents 2015;45:376-84.

213 Carasi P, Racedo SM, Jacquot C, et al. Impact of kefir derived Lactobacillus kefiri on the mucosal immune response and gut microbiota. J Immunol Res 2015;2015:361604.

214 Yoda K, He F, Miyazawa K, et al. Orally administered heat-killed Lactobacillus gasseri TMC0356 alters respiratory immune responses and intestinal microbiota of diet-induced obese mice. J App/ Microbiol 2012;113:155-62.

215 Hougee S, Vriesema AJ, Wijering SC, et al. Oral treatment with probiotics reduces allergic symptoms in ovalbumin-sensitized mice: a bacterial strain comparative study. Int Arch Allergy Immunol 2010;151:107-17.

216 Wang MF, Lin HC, Wang YY, et al. Treatment of perennial allergic rhinitis with lactic acid bacteria. Pediatr Allergy Immunol 2004;15:152-8.

217 Chou LS, Weimer B. Isolation and characterization of acid- and bile-tolerant isolates from strains of Lactobacillus acidophilus. J Dairy Sci 1999;82:23-31.

218 Macfarlane S, Furrie E, Cummings JH, et al. Chemotaxonomic analysis of bacterial populations colonizing the rectal mucosa in patients with ulcerative colitis. Clin Infect Dis 2004;38:1690-9.

219 Li CY, Lin HC, Lai CH, et al. Immunomodulatory effects of lactobacillus and Bifidobacterium on both murine and human mitogen-activated T cells. Int Arch Allergy Immunol 2011;156:128-36.

220 Kailasapathy K, Chin J. Survival and therapeutic potential of probiotic organisms with reference to Lactobacillus acidophilus and Bifidobacterium spp. Immunol Cell Biol 2000;78:80-8.

221 Meydani SN, Ha WK. Immunologic effects of yogurt. Am J Clin Nutr 2000;71:861-72.

222 Diop L, Guillou S, Durand H. Probiotic food supplement reduces stress-induced gastrointestinal symptoms in volunteers: a double-blind, placebo-controlled, randomized trial. Nutr Res 2008;28:1-5.

223 lemoli E, Trabattoni D, Parisotto S, et al. Probiotics reduce gut microbial translocation and improve adult atopic dermatitis. J Clin Gastroenterol 2012;46 (Suppl):S33-40

224 Shinkai S, Toba M, Saito T, et al. Immunoprotective effects of oral intake of heat-killed Lactobacillus pentosus strain b240 in elderly adults: a randomised, double-blind, placebo-controlled trial. Br J Nutr 2013;109:1856-65.

225 Inoue $\mathrm{Y}$, Kambara T, Murata N, et al. Effects of oral administration of Lactobacillus acidophilus L-92 on the symptoms and serum cytokines of atopic dermatitis in Japanese adults: a double-blind, randomized, clinical trial. Int Arch Allergy Immunol 2014;165:247-54.

226 Linskens RK, Huijsdens XW, Savelkoul PH, et al. The bacterial flora in inflammatory bowel disease: current insights in pathogenesis and the influence of antibiotics and probiotics. Scand J Gastroentero/ Supp/ 2001;36:(234):29-40.

227 Feher J, Kovacs I, Pacella E, et al. [Correlation of the microbiota and intestinal mucosa in the pathophysiology and treatment of irritable bowel, irritable eye, and irritable mind syndrome]. Orv Hetil 2014;155:1454-60.

228 Mizoguchi A. Animal models of inflammatory bowel disease. Prog Mol Biol Transl Sci 2012;105:263-320.

229 Scaldaferri F, Gerardi V, Lopetuso LR, et al. Gut microbial flora, prebiotics, and probiotics in IBD: their current usage and utility. BioMed Res Int 2013;2013:435268.

230 Gionchetti P, Rizzello F, Venturi A, et al. Oral bacteriotherapy as maintenance treatment in patients with chronic pouchitis: a double-blind, placebo-controlled trial. Gastroenterology 2000;119:305-9.

231 Sakai T, Kubota H, Gawad A, et al. Effect of fermented milk containing Lactobacillus casei strain Shirota on constipation-related symptoms and haemorrhoids in women during puerperium. Benef Microbes 2015;6:253-62.

232 Higashikawa F, Noda M, Awaya T, et al. Improvement of constipation and liver function by plant-derived lactic acid bacteria: a double-blind, randomized trial. Nutrition (Burbank, Los Angeles County, Calif.) 2010;26:367-74.

233 Venturi A, Gionchetti P, Rizzello F, et al. Impact on the composition of the faecal flora by a new probiotic preparation: preliminary data on maintenance treatment of patients with ulcerative colitis. Aliment Pharmacol Ther 1999;13:1103-8.

234 Ishibashi N, Yaeshima T, Hayasawa H. Bifidobacteria:Their Significance in Human Intestinal Health. Mal J Nutr 1997;3:149-59.

235 Corcoran BM, Stanton C, Fitzgerald GF, et al. Growth of probiotic lactobacilli in the presence of oleic acid enhances subsequent survival in gastric juice. Microbiology 2007;153(Pt 1):291-9.

236 Kilic GB, Karahan AG. Identification of lactic acid bacteria isolated from the fecal samples of healthy humans and patients with dyspepsia, and determination of their ph, bile, and antibiotic tolerance properties. J Mol Microbiol Biotechnol 2010;18:220-9.

237 Marteau P, Pochart P, Bouhnik Y, et al. [Survival of Lactobacillus acidophilus and Bifidobacterium $\mathrm{sp}$. in the small intestine following ingestion in fermented milk. A rational basis for the use of probiotics in man]. Gastroenterol Clin Biol Gastroenterologie 1992;16:25-8.

238 Wang $R$, Chen S, Jin J, et al. Survival of Lactobacillus casei strain Shirota in the intestines of healthy Chinese adults. Microbiol Immunol 2015;59:268-76.

239 Piano MD, Carmagnola S, Ballare M, et al. Comparison of the kinetics of intestinal colonization by associating 5 probiotic bacteria assumed either in a microencapsulated or in a traditional, uncoated form. J Clin Gastroenterol 2012;46 (Suppl):S85-92.

240 Del Piano M, Carmagnola S, Andorno S, et al. Evaluation of the intestinal colonization by microencapsulated probiotic bacteria in comparison with the same uncoated strains. J Clin Gastroenterol 2010;44(Suppl 1):S42-6.

241 Szymanski H, Chmielarczyk A, Strus M, et al. Colonisation of the gastrointestinal tract by probiotic L. rhamnosus strains in acute diarrhoea in children. Dig Liver Dis 2006:38(Suppl 2):S274-6.

242 Visich KL, Yeo TP. The prophylactic use of probiotics in the prevention of radiation therapy-induced. Clin J Oncol Nurs 2010;14:467-73.

243 Bergogne-Berezin E. Treatment and prevention of antibiotic associated diarrhea. Int J Antimicrob Agents 2000;16:521-6.

244 Eser $A$, Thalhammer $F$, Burghuber $F$, et al. [Probiotics for the prevention of antibiotic-induced diarrhea]. Z Gastroenterol 2012;50:1089-95.

245 Kelly CP, LaMont JT. Clostridium difficile infection. Annu Rev Med 1998;49:375-90.

246 Kelly CP, Pothoulakis C, LaMont JT. Clostridium difficile colitis. N Engl J Med 1994;330:257-62.

247 Boonma P, Spinler JK, Venable SF, et al. Lactobacillus rhamnosus L34 and Lactobacillus casei L39 suppress Clostridium difficile-induced IL-8 production by colonic epithelial cells. BMC Microbiol 2014;14:177.

248 Yun B, Oh S, Griffiths MW. Lactobacillus acidophilus modulates the virulence of Clostridium difficile. J Dairy Sci 2014;97:4745-58.

249 Dietrich CG, Kottmann T, Alavi M. Commercially available probiotic drinks containing Lactobacillus casei DN-114001 reduce antibiotic-associated diarrhea. World J Gastroenterol 2014;20:15837-44.

250 Shavakhi A, Tabesh E, Yaghoutkar A, et al. The effects of multistrain probiotic compound on bismuth-containing quadruple therapy for Helicobacter pylori infection: a randomized placebo-controlled triple-blind study. Helicobacter 2013;18:280-4.

251 Dinleyici EC, Dalgic N, Guven S, et al. The effect of a multispecies synbiotic mixture on the duration of diarrhea and length of hospital stay in children with acute diarrhea in Turkey: single blinded randomized study. Eur J Pediatr 2013; 172:459-64.

252 Allen SJ, Wareham K, Bradley C, et al. A multicentre randomised controlled trial evaluating lactobacilli and bifidobacteria in the prevention of antibiotic-associated diarrhoea in older people admitted to hospital: the PLACIDE study protocol. BMC Infect Dis 2012;12:108.

253 Vandenplas Y, De Hert SG, group PR-s. Randomised clinical trial: the synbiotic food supplement Probiotical vs. placebo for acute gastroenteritis in children. Aliment Pharmacol Ther 2011;34:862-7.

254 Grandy G, Medina M, Soria R, et al. Probiotics in the treatment of acute rotavirus diarrhoea. A randomized, double-blind, controlled trial using two different probiotic preparations in Bolivian children. BMC Infect Dis 2010; 10:253.

255 Fang SB, Lee HC, Hu JJ, et al. Dose-dependent effect of Lactobacillus rhamnosus on quantitative reduction of faecal rotavirus shedding in children. $J$ Trop Pediatr 2009:55:297-301.

256 Ruszczynski M, Radzikowski A, Szajewska H. Clinical trial: effectiveness of Lactobacillus rhamnosus (strains E/N, Oxy and Pen) in the prevention of antibiotic-associated diarrhoea in children. Aliment Pharmacol Ther 2008:28:154-61.

257 Lievin-Le Moal V, Sarrazin-Davila LE, Servin AL. An experimental study and a randomized, double-blind, placebo-controlled clinical trial to evaluate the antisecretory activity of Lactobacillus acidophilus strain LB against nonrotavirus diarrhea. Pediatrics 2007;120:e795-803.

258 Szymanski H, Pejcz J, Jawien M, et al. Treatment of acute infectious diarrhoea in infants and children with a mixture of three Lactobacillus rhamnosus strains-a randomized, double-blind, placebo-controlled trial. Aliment Pharmacol Ther 2006;23:247-53.

259 Sarker SA, Sultana S, Fuchs GJ, et al. Lactobacillus paracasei strain ST11 has no effect on rotavirus but ameliorates the outcome of nonrotavirus diarrhea in children from Bangladesh. Pediatrics 2005;116:e221-8.

260 Gaon D, Garcia H, Winter L, et al. Effect of Lactobacillus strains and Saccharomyces boulardii on persistent diarrhea in children. Medicina (B Aires) 2003;63:293-8.

261 Rosenfeldt V, Michaelsen KF, Jakobsen M, et al. Effect of probiotic Lactobacillus strains on acute diarrhea in a cohort of nonhospitalized children attending day-care centers. Pediatr Infect Dis J 2002;21:417-19.

262 Gaon D, Garmendia C, Murrielo NO, et al. Effect of Lactobacillus strains (L. case and L. Acidophillus Strains cerela) on bacterial overgrowth-related chronic diarrhea. Medicina (B Aires) 2002:62:159-63.

263 Shornikova AV, Casas IA, Isolauri E, et al. Lactobacillus reuteri as a therapeutic agent in acute diarrhea in young children. $J$ Pediatr Gastroenterol Nutr 1997;24:399-404.

264 Ranney RR. Classification of periodontal diseases. Periodontol 2000 1993;2:13-25. 
265 Soder B, Andersson LC, Meurman JH, et al. Unique database study linking gingival inflammation and smoking in carcinogenesis. Philos Trans $R$ Soc Lond $B$ Biol Sci 2015;370:20140041.

266 Listgarten MA. Pathogenesis of periodontitis. J Clin Periodontol 1986;13:418-30.

267 Golub LM, Ryan ME, Williams RC. Modulation of the host response in the treatment of periodontitis. Dent Today 1998;17:102-6, 08-9.

268 Adams D, Addy M. Mouthrinses. Adv Dent Res 1994;8:291-301.

269 Eley BM. Antibacterial agents in the control of supragingival plaque-a review. Br Dent J 1999;186:286-96.

270 Van Leeuwen MP, Slot DE, Van der Weijden GA. Essential oils compared to chlorhexidine with respect to plaque and parameters of gingival inflammation: a systematic review. J Periodontol 2011;82:174-94.

271 Flotra L, Gjermo P, Rolla G, et al. Side effects of chlorhexidine mouth washes. Scand I Dent Res 1971;79:119-25.

272 Samot J, Badet C. Antibacterial activity of probiotic candidates for oral health. Anaerobe 2013;19:34-8.

273 Loe $\mathrm{H}$. The gingival index, the plaque index and the retention index systems. J Periodontol 1967;38:Suppl:610-16.

274 Shimauchi H, Mayanagi G, Nakaya S, et al. Improvement of periodontal condition by probiotics with Lactobacillus salivarius WB21: a randomized, double-blind, placebo-controlled study. J Clin Periodontol 2008;35:897-905.

275 Twetman S, Derawi B, Keller M, et al. Short-term effect of chewing gums containing probiotic Lactobacillus reuteri on the levels of inflammatory mediators in gingival crevicular fluid. Acta Odontol Scand 2009;67:19-24.

276 Saha S, Tomaro-Duchesneau C, Rodes L, et al. Investigation of probiotic bacteria as dental caries and periodontal disease biotherapeutics. Benef Microbes 2014;5:447-60.

277 Alberti KG, Zimmet PZ. Definition, diagnosis and classification of diabetes mellitus and its complications. Part 1: diagnosis and classification of diabetes mellitus provisional report of a WHO consultation. Diabet Med 1998; 15:539-53.

278 Donath MY, Shoelson SE. Type 2 diabetes as an inflammatory disease. Nat Rev Immunol 2011;11:98-107.

279 Donath MY, Ehses JA, Maedler K, et al. Mechanisms of beta-cell death in type 2 diabetes. Diabetes 2005;54(Suppl 2):S108-13.

280 Yang $\mathrm{H}$, Youm $\mathrm{YH}$, Vandanmagsar B, et al. Obesity increases the production of proinflammatory mediators from adipose tissue T cells and compromises TCR repertoire diversity: implications for systemic inflammation and insulin resistance. J Immunol 2010;185:1836-45.

281 Panwar H, Calderwood D, Grant IR, et al. Lactobacillus strains isolated from infant faeces possess potent inhibitory activity against intestinal alpha- and beta-glucosidases suggesting anti-diabetic potential. Eur J Nutr 2014;53:1465-74.

282 Asemi Z, Zare Z, Shakeri H, et al. Effect of multispecies probiotic supplements on metabolic profiles, hs-CRP, and oxidative stress in patients with type 2 diabetes. Ann Nutr Metab 2013;63:1-9.

283 Hayami T, Pickarski M, Zhuo Y, et al. Characterization of articular cartilage and subchondral bone changes in the rat. Bone 2006;38:234-43.

284 Benito MJ, Veale DJ, FitzGerald 0, et al. Synovial tissue inflammation in early and late osteoarthritis. Ann Rheum Dis 2005;64:1263-7.

285 Kano H, Kaneko T, Kaminogawa S. Oral intake of Lactobacillus delbrueckii subsp. bulgaricus OLL1073R-1 prevents collagen-induced arthritis in mice. J Food Prot 2002;65:153-60.

286 So JS, Kwon HK, Lee CG, et al. Lactobacillus casei suppresses experimental arthritis by down-regulating T helper. Mol Immunol 2008;45:2690-9.

287 So JS, Song MK, Kwon HK, et al. Lactobacillus casei enhances type II collagen/ glucosamine-mediated suppression of. Life Sci 2011;88:358-66.

288 Mandel DR, Eichas K, Holmes J. Bacillus coagulans: a viable adjunct therapy for relieving symptoms of rheumatoid arthritis according to a randomized, controlled trial. BMC Complement Altern Med 2010;10:1.

289 Wu CC, Weng WL, Lai WL, et al. Effect of Lactobacillus plantarum Strain K21 on High-Fat Diet-Fed Obese Mice. Evid Based Complement Alternat Med 2015;2015:391767.

290 Jeong JJ, Kim KA, Ahn YT, et al. Probiotic mixture KF attenuates age-dependent memory deficit and lipidemia in Fischer 344 rats. J Microbiol Biotechnol 2015;25:1532-6.

291 [No authors listed]. Randomized controlled study of probiotics containing Lactobacillus casei (Shirota strain) for prevention of ventilator-associated pneumonia. J Med Assoc Thai 2015;98:253-9.

292 Oláh A, Belágyi T, Pótó L, et al. Synbiotic control of inflammation and infection in severe acute pancreatitis: a prospective, randomized, double blind study. Hepatogastroenterology 2007;54:590-4.

293 Besselink MG, van Santvoort HC, Buskens E, et al. Probiotic prophylaxis in predicted severe acute pancreatitis: a randomised. Lancet 2008;371:651-9.

294 Annibale B, Maconi G, Lahner E, et al. Efficacy of Lactobacillus paracasei sub. paracasei F19 on abdominal symptoms in patients with symptomatic uncomplicated diverticular disease: a pilot study. Minerva Gastroenterol Dietol 2011;57:13-22.
295 Bajaj JS, Heuman DM, Hylemon PB, et al. Randomised clinical trial: Lactobacillus GG modulates gut microbiome, metabolome and endotoxemia in patients with cirrhosis. Aliment Pharmacol Ther 2014;39:1113-25.

296 Zein EF, Karaa S, Chemaly A, et al. [Lactobacillus rhamnosus septicemia in a diabetic patient associated with probiotic use: a case report]. Ann Biol Clin (Paris) 2008;66:195-8.

297 Moudden MK, Boukhira A, Sarret D, et al. [Septicaemia due to Lactobacillus jensenii: bacteriological diagnostic orientation]. Annales de biologie clinique 2007;65:299-302.

298 Jureen R, Sondenaa K, Hoiby EA, et al. Lactobacillus rhamnosus septicaemia in a patient with a graft in the inferior vena cava. Scand I Infect Dis 2002:34:135-6.

299 Farina C, Arosio M, Mangia M, et al. Lactobacillus casei subsp. rhamnosus sepsis in a patient with ulcerative colitis. J Clin Gastroenterol 2001;33:251-2.

300 Land MH, Rouster-Stevens K, Woods CR, et al. Lactobacillus sepsis associated with probiotic therapy. Pediatrics 2005;115:178-81.

301 Kochan P, Chmielarczyk A, Szymaniak L, et al. Lactobacillus rhamnosus administration causes sepsis in a cardiosurgical patient-is the time right to revise probiotic safety guidelines? Clin Microbiol Infect 2011;17:1589-92.

302 Fradiani PA, Petrucca A, Ascenzioni F, et al. Endocarditis caused by Lactobacillus jensenii in an immunocompetent patient. J Med Microbiol 2010;59(Pt 5):607-9.

303 Schmidt $\mathrm{V}$, Wolter $\mathrm{M}$, Lenschow $\mathrm{U}$, et al. [Lactobacillus paracasei endocarditis in an 18-yeard-old patient with trisomy 21 atrioventricular septal defect and Eisenmenger complex: therapeutic problems]. Klin Padiatr 2001;213:35-8.

304 Suarez-Garcia I, Sanchez-Garcia A, Soler L, et al. Lactobacillus jensenii bacteremia and endocarditis after dilatation and curettage: case report and literature review. Infection 2012;40:219-22.

305 Chong Y, Lim HS, Lee SY, et al. Lactobacillus casei subspecies casei endocarditis-a case report. Yonsei Med J 1991;32:69-73.

306 Arpi M, Vancanneyt M, Swings J, et al. Six cases of Lactobacillus bacteraemia: identification of organisms and antibiotic susceptibility and therapy. Scand I Infect Dis 2003;35:404-8.

307 Bar W, Euteneuer B, Schuster S. [Bacteremia caused by Lactobacillus plantarum in endocarditis lenta]. Immun Infekt 1987;15:173-4.

308 Carretto E, Barbarini D, Marzani FC, et al. Catheter-related bacteremia due to Lactobacillus rhamnosus in a single-lung transplant recipient. Scand I Infect Dis 2001;33:780-2.

309 Chazan B, Raz R, Shental Y, et al. Bacteremia and pyelonephritis caused by Lactobacillus jensenii in a patient with urolithiasis. Isr Med Assoc J The Israel 2008;10:164-5.

310 De Groote MA, Frank DN, Dowell E, et al. Lactobacillus rhamnosus GG bacteremia associated with probiotic use in a child with short gut syndrome. Pediatr Infect Dis J 2005;24:278-80.

311 Duprey KM, McCrea L, Rabinowitch BL, et al. Pyelonephritis and Bacteremia from Lactobacillus delbrueckii. Case Rep Infect Dis 2012;2012:745743.

312 Gouriet $F$, Million $M$, Henri $M$, et al. Lactobacillus rhamnosus bacteremia: an emerging clinical entity. Eur J Clin Microbiol Infect Dis 2012;31:2469-80.

313 Kunz AN, Noel JM, Fairchok MP. Two cases of Lactobacillus bacteremia during probiotic treatment of short gut syndrome. J Pediatr Gastroenterol Nutr 2004;38:457-8.

314 Majcher-Peszynska J, Heine W, Richter I, et al. [Persistent Lactobacillus casei subspecies rhamnosus bacteremia in a 14 year old girl with acute myeloid leukemia. A case report]. Klin Padiatr 1999;211:53-6.

315 Mehta A, Rangarajan S, Borate U. A cautionary tale for probiotic use in hematopoietic SCT patients-Lactobacillus acidophilus sepsis in a patient with mantle cell lymphoma undergoing hematopoietic SCT. Bone Marrow Transplant 2013:461-2.

316 Notario R, Leardini N, Borda N, et al. [Hepatic abscess and bacteremia due to Lactobacillus rhamnosus]. Rev Argent Microbiol 2003;35:100-1.

317 Salminen MK, Rautelin H, Tynkkynen S, et al. Lactobacillus bacteremia, clinical significance, and patient outcome, with special focus on probiotic L. rhamnosus GG. Clin Infect Dis 2004;38:62-9.

318 Suarez-Quiroz M, Gonzalez-Rios O, Barel M, et al. Effect of the post-harvest processing procedure on OTA occurrence in artificially contaminated coffee. Int J Food Microbiol 2005; 103:339-45.

319 Tommasi C, Equitani F, Masala M, et al. Diagnostic difficulties of Lactobacillus casei bacteraemia in immunocompetent patients: a case report. J Med Case Rep 2008; $2: 315$

320 Robin F, Paillard C, Marchandin H, et al. Lactobacillus rhamnosus meningitis following recurrent episodes of bacteremia in a child undergoing allogeneic hematopoietic stem cell transplantation. J Clin Microbiol 2010;48:4317-19.

321 Husni RN, Gordon SM, Washington JA, et al. Lactobacillus bacteremia and endocarditis: review of 45 cases. Clin Infect Dis 1997;25:1048-55.

322 Simkins J, Kaltsas A, Currie BP. Investigation of inpatient probiotic use at an academic medical center. IntJ Infect Dis 2013;17:e321-4.

323 Burns D, Hurst JR, Hopkins S, et al. Purpura fulminans associated with Lactobacillus paracasei liver abscess. Anaesth Intensive Care 2007;35:121-3. 
324 Cukovic-Cavka S, Likic R, Francetic I, et al. Lactobacillus acidophilus as a cause of liver abscess in a NOD2/CARD15-positive patient with Crohn's disease. Digestion 2006;73:107-10.

325 Rogasi PG, Vigano S, Pecile P, et al. Lactobacillus casei pneumonia and sepsis in a patient with AIDS. Case report and review of the literature. Ann Ital Med Int 1998;13:180-2.

326 Dickgiesser U, Weiss N, Fritsche D. Lactobacillus gasseri as the cause of septic urinary infection. Infection 1984;12:14-16.

327 Russo A, Angeletti S, Lorino G, et al. A case of Lactobacillus casei bacteraemia associated with aortic dissection: is there a link? New Microbiol 2010;33:175-8.

328 Bartalesi F, Veloci S, Baragli F, et al. Successful tigecycline lock therapy in a Lactobacillus rhamnosus catheter-related bloodstream infection. Infection 2012;40:331-4

329 Wolz M, Schaefer J. "Swiss cheese-like" brain due to Lactobacillus rhamnosus. Neurology 2008;70:979.

330 Franko B, Vaillant $\mathrm{M}$, Recule $\mathrm{C}$, et al. Lactobacillus paracasei endocarditis in a consumer of probiotics. Med Mal Infect 2013;43:171-3.

331 Thomas CM, Versalovic J. Probiotics-host communication: Modulation of signaling pathways in the intestine. Gut Microbes 2010;1:148-63.
332 Di Cerbo A, Palmieri B. Lactobacillus Paracasei subsp. Paracasei F19; a farmacogenomic and clinical update. Nutr Hosp 2013;28: 1842-50.

333 Morelli L, Campominosi E. Genetic stability of Lactobacillus paracasei subsp. paracasei F19. Microb Ecol Health Dis 2002;14:14-16.

334 Charteris WP, Kelly PM, Morelli L, et al. Antibiotic susceptibility of potentially probiotic Lactobacillus species. J Food Prot 1998;61:1636-43.

335 Zarazaga M, Saenz Y, Portillo A, et al. In vitro activities of ketolide HMR3647, macrolides, and other antibiotics against Lactobacillus, Leuconostoc, and Pediococcus isolates. Antimicrob Agents Chemother 1999; 43:3039-41.

336 Danielsen M, Wind A. Susceptibility of Lactobacillus spp. to antimicrobial agents. Int J Food Microbiol 2003;82:1-11.

337 Mattila-Sandholm T, Jaana M, Saarela M. Lactic acid bacteria with health claims -interactions and interference with gastrointestinal flora. Int Dairy J 2013;9:25-35.

338 Liu H, Gao Y, Yu LR, et al. Inhibition of Staphylococcus aureus by lysostaphin-expressing lactobacillus plantarum WCFS1 in a modified genital tract secretion medium. Appl Environ Microbiol 2011;77:8500-8. 